\author{
UNIVERSIDADE DE SÃO PAULO - USP \\ FACULDADE DE ECONOMIA, ADMINISTRAÇÃO E CONTABILIDADE \\ DEPARTAMENTO DE ECONOMIA
}

UNIVERSITÉ CATHOLIQUE DE LOUVAIN

FACULTÉ DES SCIENCES ÉCONOMIQUES, SOCIALES, POLITIQUES ET DE COMMUNICATION

ÉCOLE DES SCIENCES ECONOMIQUES

\title{
The impact of INCLUSP on university access
}

\section{O impacto do INCLUSP no acesso à universidade}

Marília Gouvêa de França Pereira

Supervisors: Fernanda Gonçalves de La Fuente Estevan

Vincent Vandenberghe

São Paulo, Brasil 2019 
Prof. Dr. Vahan Agopyan

Reitor da Universidade de São Paulo

Prof. Dr. Adalberto Américo Fischmann

Diretor da Faculdade de Economia, Administração e Contabilidade

Prof. Dr. Eduardo Amaral Haddad

Chefe do Departamento de Economia

Prof. Dr. Ariaster Baumgratz Chimeli

Coordenador do Programa de Pós-Graduação em Economia 


\section{MARÍLIA GOUVÊA DE FRANÇA PEREIRA}

\section{The impact of INCLUSP on university access}

Dissertação apresentada ao Departamento de Economia da Faculdade de Economia, Administração e Contabilidade da Universidade de São Paulo e à Escola de Economia da Faculdade de Ciências Econômicas, Sociais, Políticas e da Comunicação da Universidade Católica de Louvain como requisito parcial para a obtenção da dupla-titulação de Mestre em Ciências.

Supervisors: Fernanda Gonçalves de La Fuente Estevan Vincent Vandenberghe

Versão Corrigido

São Paulo, Brasil 
FICHA CATALOGRÁFICA

Elaborada por Rafael Mielli Rodrigues - CRB-8/7286

Seção de Processamento Técnico do SBD/FEA/USP

Pereira, Marília Gouvêa de França

The impact of INCLUSP on university access / Marília Gouvêa de França Pereira. - São Paulo, 2019.

$56 \mathrm{p}$.

Dissertação (Mestrado) - Universidade de São Paulo, 2019.

Orientadora: Fernanda Gonçalves de La Fuente Estevan.

Orientador: Vincent Vandenberghe.

1. Economia da educação 2. Econometria 3. Ensino superior I. Universidade de São Paulo. Faculdade de Economia, Administração e Contabilidade. II. Título.

CDD -370.193 
To my grandparents Amadeu, Mário, Yeda, Marly and Gilda 


\section{Acknowledgements}

I thank FEA-USP for the almost eight years of the excellent education I was fortunate enough to receive and UCL for welcoming me at the double degree program for this Masters. This study was financed in part by the Coordenação de Aperfeiçoamento de Pessoal de Nível Superior - Brasil (CAPES) - Finance Code 001, and I am grateful for this support. Also, I would like to thank Fundação Universitária para o Vestibular (FUVEST) for providing the database for this dissertation.

To my supervisor Fernanda Estevan, my sincere appreciation for the guidance during both my Bachelor and my Masters' thesis'. My academic development would certainly not be this lasting without your knowledge and patience. I thank my supervisor from UCL, Vincent Vandenberghe, for the support and useful tips on this dissertation.

I would also like to thank Muriel Dejemeppe and Raphael Corbi for significant inputs to this thesis, and Ricardo Madeira and Mariana Suplicy for the support and insights along this process. Géraldine Carette, Adriana Molina, Pinho and Leka, thank you for the help on making this degree possible.

I thank Viviani Kasahara for the excellent work with the database, and Bruna Borges for the great help. Daniel, Célio, Selma, the board and staff from FUVEST, thank you.

To all my friends and colleagues at USP and UCL, thank you for the friendship and the moments of fun in the middle of a considerable amount of study. I thank especially Lucas, Menon, Fábio, Felipe, Bernardo, João, Dornellas, and Vinícius. Clara and Victoria, thank you for being such strong and inspirational women and friends.

I thank all my dear friends and family that were always there for me, and especially Stella for the conversations and presence even without being present. And I am grateful to Antonio for the amazing partnership, the support, and caring love.

To my parents, Mônica and Fábio, and my sister Laura thank you for the unconditional support and belief in my potential. I learned with the three of you how to be resilient and perseverant, things that are now part of who I am. You are the reason of this degree, and who motivates me to be the best I can be every day. I love you very much. 


\section{Abstract}

University of São Paulo (USP) implemented its first affirmative action policy (AA) for university access in 2007. However, little is known about the effects on the student body, as well as the efficacy of bonus-based AAs in general. This masters thesis carried out a detailed evaluation of this bonus-based program, INCLUSP, using a differences-indifferences approach. We measured the effect of the program on the probability of eligible applicants entering the university and analyzed the profile of students before and after the AA. Thus, we expect to both contribute to the academic literature and the public policy debate at USP and other selective universities. We find that the admission probability of eligible applicants significantly increased after the implementation of the AA and that the policy also seems to be redistributive regarding socio-economic characteristics of the admitted students.

Key-words: affirmative action. INCLUSP. University of São Paulo. bonus-based policy. quotas for university access. FUVEST. 


\section{Resumo}

A Universidade de São Paulo (USP) implementou sua primeira política de ação afirmativa (AA) para o acesso à universidade em 2007. No entanto, pouco se sabe sobre os efeitos no corpo discente, bem como a eficácia das ações afirmativas baseadas em bônus em geral. Esta dissertação realizou uma avaliação detalhada deste programa, chamado INCLUSP, usando o método de diferenças-em-diferenças. Medimos o efeito do programa na probabilidade de candidatos elegíveis entrarem na universidade e analisamos o perfil dos alunos antes e depois do INCLUSP. Com os resultados, esperamos contribuir tanto para a literatura acadêmica quanto para o debate sobre políticas públicas na USP e outras universidades. Encontramos que a probabilidade de admissão de candidatos elegíveis aumentou significativamente após a implementação da AA e que a política também parece ser redistributiva em relação às características socioeconômicas dos alunos admitidos.

Palavras-chave: ação afirmativa. INCLUSP. Universidade de São Paulo. política baseada em bônus. cotas na universidade. FUVEST. 


\section{Contents}

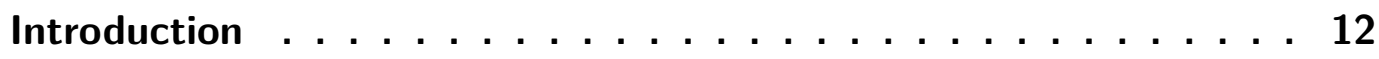

1 UNIVERSITY ADMISSION SYSTEM AND AFFIRMATIVE ACTIONS IN BRAZIL . . . . . . . . . . . . . . . . . . 17

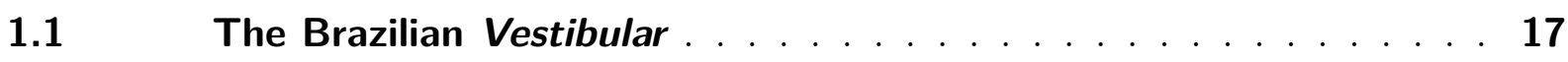

1.2 Brazilian Affirmative Actions for University Access . . . . . . . . 18

2 THE ADMISSION EXAM AND THE AFFIRMATIVE ACTION OF

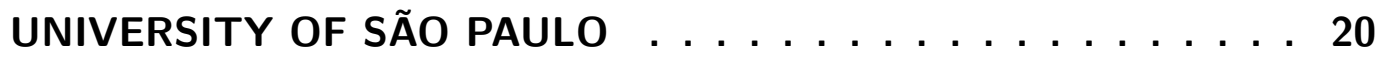

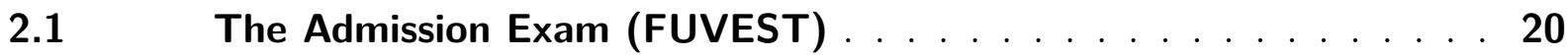

2.1 .1 The First Phase . . . . . . . . . . . . . . . . . . . . 21

2.1 .2 The Second Phase . . . . . . . . . . . . . . . . . . . 22

2.2 The Affirmative Action Policy of the University of São Paulo (IN-

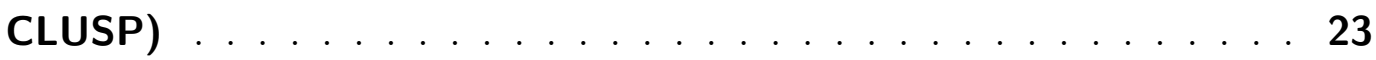

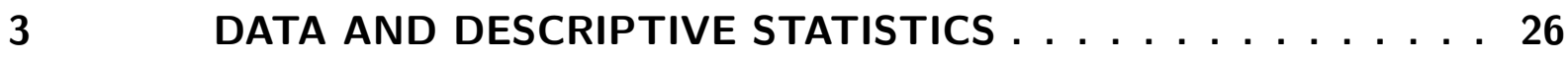

$4 \quad$ THE IMPACTS OF INCLUSP ON UNIVERSITY ACCESS $\ldots \ldots 30$

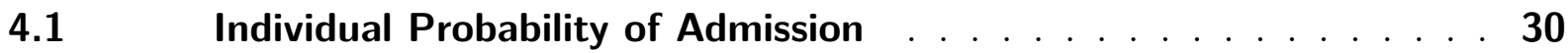

4.1.1 The differences-in-differences model . . . . . . . . . . . . 30

$4.1 .2 \quad$ Parallel Trends Assumption . . . . . . . . . . . . . . . . 33

$4.1 .3 \quad$ Results . . . . . . . . . . . . . . . . . . 36

4.2 Redistribution according to Socioeconomic Characteristics . . . . . 43

$4.3 \quad$ Confounding Factors and Behavioral Effects . . . . . . . . . 46

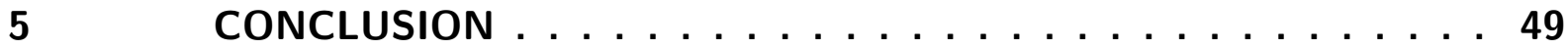

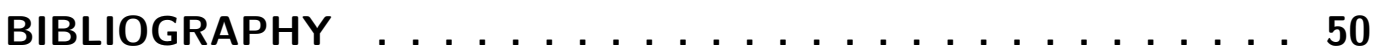

$\begin{array}{ll}\text { APPENDIX } & 52\end{array}$

APPENDIX A-TABLES $\ldots \ldots \ldots \ldots \ldots \ldots$ 


\section{List of Figures}

Figure 1 - Public School Aplicants at USP/UNICAMP per year . . . . . . . . . 47

Figure 2 - Visible Minority and Female Applicants at USP/UNICAMP per year . 47 


\section{List of Tables}

Table 1 - INCLUSP's maximum bonus over the years . . . . . . . . . . . . . 24

Table 2 - Descriptive Statistics $(2000$ - 2014) . . . . . . . . . . . 27

Table 3 - Descriptive Statistics $(2006$ - 2008) . . . . . . . . . . . . 28

Table 4 - Descriptive Statistics $(2012$ - 2014) . . . . . . . . . . . . 28

Table 5 - Admission Probability without INCLUSP (2004 - 2005) . . . . . . . 33

Table 6 - Admission Probability without INCLUSP (2005 - 2006) . . . . . . . . 34

Table 7 - Year Dummies without INCLUSP $(2000$ - 2006) . . . . . . . . . 35

Table 8 - Admission and Affirmative Action (2006 - 2008) . . . . . . . . 36

Table 9 - Admission and Affirmative Action (2004 - 2014) . . . . . . . . . . 37

Table 10 - Enrollment and Affirmative Action (2006 - 2008) . . . . . . . . . . . 39

Table 11 - Enrollment and Affirmative Action (2006 - 2009) . . . . . . . . . . 40

Table 12 - Graduation and Affirmative Action (2006 - 2009) . . . . . . . . . . 41

Table 13 - Year Dummies and Affirmative Action (2004 - 2014) . . . . . . . . . . . 41

Table 14 - Continuous Treatment Variable and Affirmative Action (2004 - 2014) . . 42

Table 15 - Descriptive Statistics of Displacing and Displaced Applicants (2008 - 2014) 44

Table 16 - Descriptive Statistics of Displacing and Displaced Applicants (2008) . . 44

Table 17 - Descriptive Statistics of Displacing and Displaced Applicants (2014) . . 45

Table 18 - Eligible Applicants Descriptive Statistics (2000 - 2014) . . . . . . . . . . 48

Table 19 - Ineligible Applicants Descriptive Statistics (2000 - 2014) . . . . . . . . . 48

Table 20 - Admission Probability without INCLUSP (2000 - 2001) . . . . . . . . 53

Table 21 - Admission Probability without INCLUSP (2001 - 2002) . . . . . . . . 53

Table 22 - Admission Probability without INCLUSP (2002 - 2003) . . . . . . . . 54

Table 23 - Admission Probability without INCLUSP (2003 - 2004) . . . . . . . . 54

Table 24 - Admission and Affirmative Action (2006 - 2009) . . . . . . . . . . . 55

Table 25 - Admission and Affirmative Action (2006 - 2012) . . . . . . . . . 55

Table 26 - Admission and Affirmative Action (2006 - 2013) . . . . . . . . . . 56

Table 27 - Competitive Majors and Affirmative Action (2004 - 2014) . . . . . . . . 56 


\section{Introduction}

In the past decade, Brazil has experienced significant improvement on the access to primary education: the rate of 16 years old students with at least eight years of study went from $50 \%$ to $71 \%$ between 2001 and 2012. ${ }^{1}$ However, the country still struggles with promoting access to higher education, which has been facing a demand increase. ${ }^{2}$ According to Oliveira (2007), the primary public education in Brazil still promotes social exclusion of its students, caused by insufficient learning, which leads to barriers to its students to access university. Besides, Francis and Tannuri-Pianto (2012a) found evidence that socioeconomic status is also responsible for these substantial barriers, alongside with race and gender. In Brazil public universities have, on average, higher or equal quality to private universities. Thus, the majority of Brazilian students compete for the same spots in higher education, despite having different economic, social and educational conditions. ${ }^{3}$

The importance of obtaining a college diploma to raise one's social status and income - especially in a developing country such as Brazil - explains the use of many college affirmative action policies (AA) in the country. These AAs increased significantly in the last years and go beyond the well-known social and racial quotas: they may have several characteristics, such as the use of bonus on the college admission exam rather than the reservation of spots. Universidade de São Paulo ${ }^{4}$ (USP) implemented its first AA in 2007 using a bonus-based program, INCLUSP. The program applies a bonus to the eligible applicants' scores in USP's admission exam - FUVEST -, to raise these applicants' final score. This dissertation aims to evaluate the impact of INCLUSP on the applicants' probability of getting admitted and on the profile of those who get in.

Similarly to other AAs in Brazil, INCLUSP's main objective was to encourage both the participation of students from public schools in the university's admission exam (FUVEST) and the access rate of those students to USP - the university intended to reach a rate of $50 \%$ of the students coming from the public high school system in 2018, and in the year of its implementation (2007) this rate was 26,5\%. This discrepancy between admitted students in terms of high school type is not exclusive from USP. It is faced by most public universities in Brazil, and reveals not only the difference in the quality between public and private high school students, but the difficulty that the less privileged children have when it comes to university access in comparision to students from private high schools.

1 Source: PNAD/IBGE.

2 According to IBGE (2008), the enrollment rate of the higher education in Brazil has gone from 16,5\% in 2001 to $34,6 \%$ in 2015 .

3 Since families from upper social classes can provide their children with primary private schooling, which on average has higher quality than primary public schools. See Zago (2006) and Carnavale (2003).

4 In English, University of São Paulo. 
Therefore, as already mentioned, AAs in Brazil and INCLUSP are a strategy to help students with lower socio-economic backgrounds to have an opportunity of increasing their social status and obtaining an education of excellence.

Even though INCLUSP has been functioning for over a decade, little is known about its results. Matos et al. (2012) show, when looking at aggregate FUVEST's data from 2001 to 2010, that although the program reached the goal of increasing the rate of public high school graduates at USP, the number of applicants from public schools has significantly decreased. According to them, this might have mitigated the effect of INCLUSP. Using their main results and expanding the analysis, Piotto and Nogueira (2016) show that although more students from public schools got into USP after the AA, INCLUSP was not capable of eliminating significant barriers to the university access. Besides, Daflon, Junior and Campos (2013) suggest that, in general, bonus-based programs are less efficient in promoting access than regular quotas, and that USP would be one example of that.

Since the literature related to INCLUSP is limited, regarding both data and methodology, it becomes relevant to work with a broader period of data and search for more detailed results. Also, INCLUSP went through several changes since its creation until 2016, which allows for a more profound evaluation. Thus, the magnitude of the impact of a bonus-based AA is the primary goal of this study. Since we have detailed data at the individual level from an extended period of the program, we intend on performing a more complete evaluation of INCLUSP.

The existing literature on AA policies is non-consensual and mainly derives from evidence from the United States. Some of the approaches to this subject are evaluations of AAs regarding redistribution of university spots to less privileged students; impact evaluations of these policies on the students' effort; and research into their impact in the long run, among others. In Brazil and other countries (e.g., India), the literature has been growing in the past decade, and the main results corroborate those found in American literature. In the United States most of the AAs are race-based, that is, the beneficiaries of the programs are those self-declared blacks. Sander (2004) found that with the AAs, not only black students were approved in more prestigious schools than they usually would have been, but also approximately $14 \%$ of all black students accepted would not have been admitted in any school in the absence of AAs. Rothstein and Yoon (2008) found similar results, stating that the proportion of black students in US law schools would decline if AAs did not exist in both elite and general schools.

Some American states such as Louisiana, Mississippi, Texas, and California banned affirmative actions for university access in 1996 from public universities (CHAN; EYSTER, 2003). ${ }^{5}$ Card and Krueger (2005) analyzed the effect of these suspensions in California and

\footnotetext{
5 Also, in 2006, the same suspension occurred in the states of Michigan, Nebraska, Arizona and New
} 
Texas on the candidates' profiles using a differences-in-differences model and the SATs scores and their results suggest that the absence of AAs does not discourage minority students from applying.

On the other hand, Dickson (2006) found evidence that the suspension of the AAs in Texas made the number of black and Hispanic candidates decrease substantially, a result that was corroborated by Hinrichs (2012), who analyzed the suspension in several states. Chan and Eyster (2003) argue that the universities in the states affected by the decision circumvented the suspension of racial AAs by giving lower weight to standardized tests (such as the SATs) and higher weight to other indicators such as high school outcomes and different classifications, where minorities typically perform better when compared to SATs. ${ }^{6}$

In 2003 the US Supreme Court overturned the suspension of affirmative action in Texas after Grutter vs. Bollinger (AKHTARI; BAU, 2016), which allowed many researchers to investigate the impacts of these decisions. Using a method of differences-in-differences, Akhtari and Bau (2016) found that this event contributed to the substantial reduction of the achievement gap between white students and visible minority students in high school. They also identified that students coming from minorities were more likely to enroll in university selection processes after such a court decision.

In Brazil, Francis and Tannuri-Pianto (2012b) studied one of the first AAs of the country, the racial quotas of the Universidade de Brasilia(UnB). ${ }^{7}$ They found that, like in the USA, the AA increased the proportion of self-reported black and brown students, and that students that benefited from them came from less privileged families. ${ }^{8}$ Junior and Waltenberg (2015) see similar results when carrying out several simulations based on admission data from the 2010 admission exam of the Universidade Estadual do Rio de Janeiro(UERJ). ${ }^{9}$ However, they discover that benefited students would be over-represented in courses of low prestige and under-represented in those of high renown. These results suggest that affirmative action policies with exclusively racial criteria can correct racial inequality in access to university, but may contribute little to the economic rise of selfdeclared black, brown or indigenous students. ${ }^{10}$ Also, Daflon, Junior and Campos (2013) stated that affirmative action of Brazilian universities use blurred criteria and that reflected negatively on the public opinion.

\footnotetext{
Hampshire (HINRICHS, 2012).

6 According to them, the suspension of racial AAs reduced the quality of the approved students.

7 In English, University of Brasília.

8 Also, they found evidence that quotas did not make the candidates' effort on the access exam to decrease.

$9 \quad$ In English, State University of Rio de Janeiro.

10 Looking at performance, Assunção and Ferman (2015) studied cases from three Brazilian universities that implemented an aggressive racial quota system and found that the students benefited by the AA presented a performance on average $18 \%$ worse than the ineligible students.
} 
Lastly, Estevan, Gall and Morin (2019) analyzed the impact of the AA policy implemented by the Universidade Estadual de Campinas ${ }^{11}$ (UNICAMP) in 2005, which is very similar to INCLUSP. ${ }^{12}$ Their results state a higher approval of students from public schools in the university's admission exam after the implementation of the AA. However, the bonus did not seem to influence the decision of the public school students to apply to the university.

As already stated, this masters thesis aims to evaluate the implementation of INCLUSP, USP's affirmative action program. Since university admission processes in Brazil are made almost exclusively through objective exams, the scores of candidates are directly comparable between different students and years. That gives an advantage to Brazil relative to other countries, such as the United States, which have admission processes that combine objective criteria to subjective ones (e.g., interviews), and allows for more specific impact evaluations of related AAs. In that way, the relevance of empirical assessments of policies like INCLUSP become clear.

Considering that INCLUSP is a bonus-based program, meaning that it applies a bonus to the eligible candidates' scores in USP's admission exam - FUVEST -, this evaluation consists of three steps. The first one identifies the effect of the affirmative action on university access, searching for the change in the probability of access of an eligible candidate after the implementation of the program. The second one analyzes the differences between the displaced and the displacing candidates - where the term displacing refer to beneficiaries of the program that would not have been admitted if INCLUSP did not exist, and the displaced are ineligible students who lost their places to the beneficiaries. The third step analyzes the existence of potential confounding factors and behavioral effects, identifying possible changes resulting from the decision of the students to register or not in the admission exam.

We estimated the effect of INCLUSP on university access mainly through a method of differences in differences, where the control group are ineligible students, and the treatment group is the eligible students. When analyzing the effect of INCLUSP on the probability of admission of different types of candidates at USP, we contribute to the evaluation of the program as a whole, showing the effect of the program on the student body of the university.

The results show that the admission probability of eligible candidates increased around two percentage points one year after the implementation of INCLUSP. This increase represents around $50 \%$ of the pre-existing gap between private and public school students. When looking at a broader period, around seven years after the beginning of the AA and after a significant improvement on the size of the bonus, this probability was still rising at a similar

11 Ìn English, State University of Campinas.

12 The affirmative action program of UNICAMP consists of granting bonuses to students from public schools that may be cumulative with a bonus for self-declared black, brown or indigenous students. 
magnitude. The results also show a considerable increase in the enrollment and graduation probability of the admitted eligible students. There is no evidence that the inclusion of a racial bonus in the program in 2014 had any effect on this probability, even though we only observed the results from the very first year after this bonus implementation. Finally, we found that the majority of displacing applicants came from families with significantly lower socioeconomic status than the displaced ones.

Section 1 brings an overview of the context of affirmative actions for university access in Brazil. In Section 2 we present in detail the admission process of the University of São Paulo, FUVEST, and the AA here evaluated, INCLUSP. Section 3 details the database used in this thesis, and Section 4 contains the methodology and main results. 


\section{University Admission System and Affirma- tive Actions in Brazil}

\subsection{The Brazilian Vestibular}

Universities in Brazil follow an admission system that contains mainly one admission exam. That means that each university - or group of universities - designs its exam, which is called by vestibular in Portuguese. It is important to stress that the existence of a test such as the vestibular to university access is mandatory by law in the country.

The vestibular selects applicants to different fields of study, according to their academic achievement in the exam, which covers the Brazilian high school curriculum. That means that there are no subjective criteria taken into consideration in the vestibular. Nowadays, even though a few private universities use instruments such as interviews to complement their admission processes, many public universities still use the vestibular as the only instrument to select their students. Besides, most universities in Brazil always had a different exam. This used to create some barriers for the applicants since usually the vestibular was only available in the city and state where the university is. Therefore, if students wanted to take the exam of a university from another state, they had to travel at their expenses to do that.

Until 2012, most of the national public universities also had their specific exam. In that year, the Education Ministry (MEC) reformulated the pre-existing Exame Nacional de Ensino Médio ${ }^{1}$ (ENEM) into a unified exam. ${ }^{2}$ Nowadays, the state obliges the federal public universities to consider ENEM as the only exam in their admission processes. However, every year more universities - both private and public - have been choosing to use the applicants' score at this unified exam as their vestibular.

Differently from other countries, the admission exam in Brazil is year-specific. Therefore, if a student takes the vestibular from a university and get in her chosen major, she cannot use her score to enter the university again a few years later, even if she did not accept the spot at the time. Also, usually the students have to choose their field of study before taking the exam. ${ }^{3}$

1 High School National Exam was an exam that measured abilities of high school graduated from the whole country.

2 The new ENEM is similar to the American Scholastic Assessment Test (SAT). Since students can take ENEM in all of the states and most of the cities in Brazil, this allowed them to apply for different universities around the country without leaving their state.

3 Hence, it is common for students in Brazil to take the exam more than once if they want to change majors or universities. 
Since universities have limited spots for each major, the more competitive this is, the higher is the score needed in the vestibular for the applicant to get in the chosen one. As already mentioned, since in Brazil public universities have higher or equal quality than the private ones, the vestibular for public universities are high-stake exams, especially in the most competitive majors such as Medicine, Engineering and Psychology. Finally, for most universities, the exam happens once a year, which means students that do not get in the major chosen need to study one more year to retake the exam. Next, we will present the context of affirmative actions for university access in Brazil.

\subsection{Brazilian Affirmative Actions for University Access}

Affirmative action policies emerged in the United States, which became concerned about the inclusion of minorities in the labor market and higher education shortly after the Civil Rights Act of 1964. In Brazil, AAs for university admission began in 2003, when the Universidade Estadual do Rio de Janeiro ${ }^{4}$ (UERJ) created a system of quotas for access to their undergraduate courses, using both the social and the racial criterion. After changes over the years, the college entrance examination now assigns $20 \%$ of the vacancies to public school students and $20 \%$ for blacks, browns, and indigenous. ${ }^{5}$ Soon after UERJ, the Universidade Nacional de Brasilia ${ }^{6}$ (UnB) was the first federal university to adopt the system of quotas and to approve the reservation of spots exclusively for applicants self-declared blacks, browns and indigenous.

After UERJ and UnB implemented AA policies, other Brazilian public universities started to adopt practices of this kind. In 2011 there were 70 federal and state public universities with affirmative action programs in Brazil (DAFLON; JUNIOR; CAMPOS, 2013). Besides, the most popular type of AAs were quotas for public high school students.

Even with the increase of AAs since 2003, the big step for them in Brazil took place in 2012, when the Federal Government approved Law 12.711 known as Law of Quotas. ${ }^{7}$ This law obliges universities, institutes, and federal centers to reserve $50 \%$ of the vacancies offered in each course to eligible students, public high school graduates. ${ }^{8}$ Also, a minimum percentage of spots for black, brown and indigenous is mandatory, taking into account the

4 In English, State University of Rio de Janeiro.

5 Besides extra $5 \%$ for children of police officers, firefighters, and prison officers killed or disabled on account of their service and disabled people in general. The gross per capita income required to compete for the selection is 1.5 minimum salaries for all beneficiary groups.

$6 \quad$ In English, University of Brasília.

7 Daflon, Junior and Campos (2013) affirm that affirmative actions in higher education were initiated through local initiatives mainly from state universities, but were intensified with the Law of Quotas in recent years.

8 Of the reserved spots, half should go to public school students with monthly family income per person equal to or less than 1.5 minimum wage and the other half should be filled by public school students with monthly family income per person higher than 1.5 minimum wage. 
state's racial distribution of the last Brazilian census.

However, quotas are not the only type of AAs for university access in Brazil, and Universidade de São Paulo $^{9}$ (USP) is one example. They created their first affirmative action before the Law of Quotas, and it is a bonus-based policy, which means that it applies a bonus to the applicants' score in the vestibular. The AA also went through several changes since its creation, especially after 2012, developed in the next section. Another large university that adopts a bonus-based AA since 2005 is Universidade Estadual de Campinas ${ }^{10}$ (UNICAMP) that is also in the state of São Paulo and one of the main competitors to USP. Next, we will explain the characteristics and evolution of INCLUSP and USP's admission process.

9 In English, University of São Paulo.

10 State University of Campinas 


\section{The admission exam and the affirmative ac- tion of University of São Paulo}

\subsection{The Admission Exam (FUVEST)}

Universidade de São Paulo (USP) is the largest and most prestigious university of Brazil. It has ten campuses distributed around the state of São Paulo, but the biggest one is in São Paulo city. ${ }^{1}$ The university has approximately 93,000 students (between college and graduate levels) and 250 major options. Each year, its admission process offers almost 10,000 college level spots in different fields of study, and around 140,000 students apply to compete for these spots.

The foundation responsible for performing USP's annual admission exam is Fundação Universitária para o Vestibular ${ }^{2}$ (FUVEST). FUVEST was created in 1976 to conduct the university's admission exam, according to guidelines established by the Graduation Council of the University of São Paulo. They provided the database for this study, which contains information between the years 2000 and 2014 at the applicant level.

The exam consists of two phases, which happen in different times of the year: the first phase is a multiple choice exam, and it takes place in November; the second phase consists of three days of written questions, and it takes place in January of each year. Both phases test regular subjects from the Brazilian high school curriculum. Only the successful applicants in the first phase can write the second phase.

Besides, FUVEST allows students of the first or second year of high school to take the exam as "trainers" that is, only to practice the exam, but without actually competing for a place in the university. ${ }^{3}$ We will exclude these students from the sample. Finally, some courses, such as Music and Arts, require specific skills tests, that take place before or during the second phase of the vestibular.

As other Brazilian vestibular, FUVEST is an objective admission process. This benefits this study once the goal is to measure the impact of a specific policy - in this case, the AA - in the probability of eligible students getting in the university. If USP's admission process had subjective criteria, it would be harder to verify their isolated effect in the applicant's admission probability. In the next subsections, we will explain both the first

1 São Paulo is the largest in Latin America, with around 12 million inhabitants.

2 In English, University's Vestibular Foundation. The name FUVEST is not only the name of the foundation but also the name of the exam itself.

3 In this case, applicants must choose between three generic careers, which will only affect the content of the second phase exam for them. 
and the second phases of the exam in detail.

\subsubsection{The First Phase}

Between 2006 and 2014, FUVEST's first phase consisted of multiple choice questions divided between the high school compulsory content of Mathematics, Portuguese, History, Geography, Chemistry, Physics, English, and Biology. In 2006, the first phase had 100 multiple choice questions. From 2007 on, FUVEST included interdisciplinary items, and also changed the exam size to 90 questions.

From 2006 to 2009 there was still an increase of up to $20 \%$ in the first phase score for all students according to their performance in the ENEM exam. ${ }^{4}$ That is, the students who performed the ENEM of the same year received an increase in their score of the first phase that varied according to their performance in both FUVEST and ENEM. These were only extra points - ENEM did not decrease one student's score at FUVEST. ${ }^{5}$

The modifications to FUVEST over the years have little or no impact on this study. Since we will search for changes in the pool of admitted applicants, the essential information we will use is if the applicant was or not approved in the process. Therefore, a different number of questions or additional points due to ENEM will not affect our results, once we are mainly interested in the socio-economic characteristics of accepted and rejected applicants.

The criterion used to define the so-called cutoff score, that is, the threshold that establishes whether or not the applicant was approved to take the second phase of the exam, followed the same methodology throughout the entire period analyzed in this study. To define the number of students accepted for the second phase, FUVEST always took in consideration the number of spots available for each field of study and selected a number of applicants that summed 1.4 to 3 candidates per place. After ranking the applicants, they choose the ones that have the best performance in the first phase exam and exclude the others. However, since the criterion for selecting the number of approved applicants for the second phase varied among the years, the number of students that wrote the second phase of the exam for each major also varied. For example, if a particular field of study has 50 spots in total, the number of candidates approved for the second phase exam varied between 70 and 150, depending on the year analyzed.

4 As already mentioned, ENEM suffered many changes in 2012, and before that, the exam was not part of the admission process of several universities.

5 FUVEST no longer considered the ENEM from 2009 on as a way to increase points to the final first phase score of an applicant. 


\subsubsection{The Second Phase}

As already mentioned, FUVEST's second phase consists of three days of written questions. The first one was always a Portuguese exam, having both written problems and an essay for all applicants, regardless of their chosen field of study. Between 2006 and 2009, the subjects of the following days of exam depended only on the applicant's major. ${ }^{6}$ Thus, the weight of each day of the test varied according to the number of specific exams of each major. Between 2010 and 2014, the first two days of the second phase became common to all fields of study, with the second one including all the content from the High School curriculum. ${ }^{7}$ Finally, the third day of the exam became the specific exam, that would depend on the chosen field of study to determine the subjects of the essay questions. ${ }^{8}$

The final score of each applicant takes into account all the exams, both in the first and in the second phase. However, the weight of each one of them varied over the years. From 2012 until nowadays, each exam - where the first phase is one and each of the second phase's days are considered one - has the same weight in the calculation of the applicant's final grade (each day represents $25 \%$ of the final score of the applicant), used to determine whether or not the applicant got in the university. Naturally, only the applicants that take the second phase exam have a final score, if they attended all of the days of the vestibular and did not get eliminated.

Once FUVEST calculates the final score, the applicants are ranked, and the number of successful students depends on the number of spots available on the major that they chose. After that, the first round of calls invites successful applicants to the university. If not all the students accept the spot and enroll at the university, there are subsequent calls to fill all the places available. In this study, we will look both into the pool of admitted applicants in the university and the pool of enrolled students in the university.

FUVEST is a long exam, to which the candidates put a lot of effort into, due to its size and competitiveness. Besides, since the cutoff score changes every year - once it relies on the scores of each year's applicants - all students have the incentive to perform their best in each day of the exam, to optimize their chances of getting into USP. These are factors that encourage all types of students to perform their best every year, and it is relevant to this analysis because it suggests that a policy such as INCLUSP would not influence the applicants' effort. Since a change in the students' effort due to INCLUSP would be harmful to this study, this appears as an advantage to us. Next, we will present the policy evaluated in this study, INCLUSP, in a more detailed way.

\footnotetext{
6 Most areas of study had two other days of specific tests, while some had only one or three days of specific exams

7 History, Geography, Mathematics, Physics, Chemistry, Biology, and English, as well as interdisciplinary questions.

8 The fourth day of tests, called the Specific Skills test, remained for some areas of study.
} 


\subsection{The Affirmative Action Policy of the University of São Paulo (INCLUSP)}

INCLUSP is the affirmative action of the Universidade de São Paulo ${ }^{9}$ (USP). It began in 2007 and consists, until nowadays, of the addition of a bonus to the FUVEST's exam scores of the eligible applicants - public high school graduates. That is, like the aforementioned affirmative action of the Universidade Estadual de Campinas $^{10}$ (UNICAMP), INCLUSP does not use quotas as an AA. As already mentioned, USP created this program intending to encourage both the participation of students from public schools in the university's admission exam and the access rate of those students to the university.

To implement INCLUSP, FUVEST first applies the bonus to the first phase score to determine the second phase applicants. After the second phase, the bonus is removed from the first phase and applied to the final score - which also considers the first phase-, to avoid an overlap of bonuses. Thus, calling the individual bonus $b$, and the final score without any bonus $S$, we can write the expression for the calculation of the final score of an eligible applicant:

$$
\mathrm{S}_{\text {bonus }}=b * S
$$

Where $S_{\text {bonus }}$ is the final score for an eligible applicant. The evolution of the program (Table 1) is clear since its first implementation: in 2007, the maximum bonus of a qualified applicant - a public high school graduate - was 3\%, and in 2015 the maximum bonus rose to $25 \%$. This increase was not only due to the speculation that the first bonus was not helping the program reach its objective but also to the inclusion of another criterion. In 2013, they included an additional 5\% bonus for self-declared blacks, browns, and indigenous. In other words, the AA in question combines, since 2013, the two most used criteria of affirmative actions of Brazilian universities: the social and the racial ones.

INCLUSP has a second program, called Programa de Avaliação Seriada da USP ${ }^{11}$ (Pasusp), which targets public high school students who have also attended public elementary schools. It consists of a series of other exams that add a second bonus to the INCLUSP one depending on the applicants' performance. The program is exclusive for students still in high school when applying for FUVEST and that do not get disqualified in the first phase of the exam. However, since it is very recent - Pasusp was created in 2011 - we will not analyze it in

9 In English, University of São Paulo.

10 In English, State University of Campinas.

11 In English, University Assessment Program. 
Table 1 - INCLUSP's maximum bonus over the years

\begin{tabular}{|c|c|}
\hline Year & Maximum Bonus \\
\hline 2007 & $3 \%$ \\
\hline 2008 & $3 \%$ \\
\hline 2009 & $12 \%$ \\
\hline 2010 & $12 \%$ \\
\hline 2011 & $12 \%$ \\
\hline 2012 & $15 \%$ \\
\hline 2013 & $20 \%$ \\
\hline 2014 & $25 \%$ \\
\hline 2015 & $25 \%$ \\
\hline
\end{tabular}

this work. Therefore, we will exclude from the sample students that got into USP due to this second program.

Nowadays, the magnitude of the INCLUSP bonus is not the same for all eligible applicants. Even though the most basic eligibility criterion is public high school attendance since 2009 applicants that also attended public elementary school are entitled to more significant bonuses. Besides, as already mentioned, there is also a racial bonus of an additional $5 \%$ since 2013. That means that until 2009, all the eligible candidates had a fixed premium of $3 \%$ to their score, and from 2010 on, this bonus varied between students. In the database used in this study, we have information on the final bonus of each student, which is our main variable of interest.

As already mentioned, INCLUSP differs from the main affirmative actions in Brazil, especially since the Law of Quotas in 2012. Quota systems are the most known type of college AAs, in Brazil and around the world. A bonus system such as INCLUSP, besides allowing different criteria without restricting the number of spots for each eligible group, ${ }^{12}$ also guarantees that the scores of the benefited students are lower than the ineligible students' by only a maximum amount. On the one hand, this allows for a more flexible admission and the number of admitted eligible students might turn out to be even higher than a pre-established percentage in a quotas scenario. On the other hand, the lack of a pre-established number of spots might cause an underrepresentation of eligible students on the most competitive courses, where the maximum bonus (in this case, 25\%), might not be enough to approve what the university considers a good number of eligible students. Besides, in terms of public acceptance, the fact that the score of the eligible admitted students is lower than the ineligible students' score by a limited amount works in favor of the bonus system instead of the quotas one, which generally receives a lot of criticism.

Furthermore, as Equation (2.1) shows, since the final score of the eligible candidate is the

12 The Law of Quotas establishes that $50 \%$ of the spots should go to public school students and within the reserved spots $50 \%$ should go to for self-declared black, brown or indigenous students. 
product of her original score and the bonus, the higher the original score of the qualified candidate, the higher is her bonus. Since the original scores depend not only on the school quality - and, in general, more privileged students study at better public schools -, but also in the students' background, the share of public school students that have better backgrounds and opportunities tend to have higher original scores. Therefore, this same group ends up receiving more significant INCLUSP bonuses, and this might indicate one type of distortion of the program: since less privileged students usually have lower scores, students benefited by the AA might still face an issue of getting into the most competitive careers, even with the bonus.

In addition to these factors, Table 1 shows that FUVEST was able to implement changes to INCLUSP across time. However, there is no evidence on how FUVEST decided the magnitude of the bonus each year and if the yearly admission rate of public school students in the university was the only factor taken in consideration to make these changes. This fact showcases the importance of looking into the outcomes of the program from an empirical perspective, to identify whether the program and its modifications helped FUVEST reaching its goal or not. These are some program-specific characteristics that differ bonus policies from quotas programs, and factors that need to be taken into consideration when studying one or another. In the next section, we describe the utilized data and the main descriptive statistics from the sample considered in this study. 


\section{Data and Descriptive Statistics}

FUVEST provided the database used in this study. It contains the scores of all the individuals who wrote USP's vestibular from 2000 to 2014, that is, seven years before and seven years after the implementation of INCLUSP. The dataset also lists all applicants who, once approved, enrolled in the university, and contains their socioeconomic characteristics, as well as information on the non-admitted students. Among other variables of interest, we will observe their gender, race, type of high school (public or private) and their parents' education level. With this dataset, we can see the applicants' scores in both phases of the exam, the magnitude of the bonus received by different applicants, the position of each student in the vestibular and their career options, among other information.

To select our population of interest, we drop some of the observations. These are the aforementioned "trainers" and applicants that are not applying for a major in USP - since other few institutions, such as São Paulo's state police, use FUVEST in their admission process. These two groups represent around 9 percent of the original population. Also, we drop applicants that enrolled in the exam but did not write it (7.3 percent of the original population) and those who do not have socioeconomic information (around 2.7 percent of the original population), besides other observations that do not fit our analysis. Considering that there is an overlapping of these characteristics between the applicants, the deleted observations sum around 17 percent of the original sample.

It is essential to mention that there is a lack of socioeconomic characteristics in the 2007 sample: around 30.000 applicants did not fill out the socioeconomic section, and it is the only year with this amount of missing information. Since this study depends on this type of data, we considered the sample from two periods: 2000-2006 and 2008-2014. This restriction does not harm our analysis in any way since 2007 was the year of the implementation of the policy. Therefore, we will consider the years immediately before and immediately after INCLUSP's start, which are the years we need to perform our analysis.

In this thesis, we analyzed the impact of the implementation of INCLUSP - which began in 2007 -, the inclusion of the racial criterion in the program in 2014 and the effect of the gradual increase in the maximum bonus obtained by the eligible applicant, in years such as 2009, 2012 and 2013. To do that, we performed subsequent analysis, considering different years as the post-AA year, which we will detail in Section 4 . This allowed us to assess not only the effect of the creation of INCLUSP but also the impact of significant changes in the policy.

Tables 2 to 4 carry the descriptive statistics of our final sample. Table 2 shows the applicants characteristics for the whole set, differentiating between the years before INCLUSP and 
the years after the implementation of the AA. Tables 3 and 4 look into more restricted periods of time: Table 3 compares the descriptive statistics between 2006 and 2008, and Table 4 looks into the years of 2012 and 2014, to check if there was any significant change in the applicants' characteristics with the inclusion of the racial bonus at the beginning of 2014 .

Table 2 - Descriptive Statistics (2000 - 2014)

\begin{tabular}{lccc}
\hline \hline & Pre AA & Post AA & Difference \\
Public High School (\%) & 35 & 24 & $11^{* * *}$ \\
Visible Minority (\%) & 16 & 16 & $0^{* * *}$ \\
Female (\%) & 55 & 54 & $1^{* * *}$ \\
Technical High School (\%) & 10 & 5 & $5^{* * *}$ \\
Age & 19.28 & 18.92 & $0.36^{* * *}$ \\
Mother without HS Degree (\%) & 31 & 17 & $14^{* * *}$ \\
Mother with HS Degree (\%) & 22 & 23 & $-1^{* * *}$ \\
Mother with Univ. Degree (\%) & 38 & 51 & $-14^{* * *}$ \\
Father without HS Degree (\%) & 30 & 18 & $12^{* * *}$ \\
Father with HS Degree (\%) & 17 & 21 & $-4^{* * *}$ \\
Father with Univ. Degree (\%) & 42 & 50 & $-8^{* * *}$ \\
Previous University Attendance (\%) & 10 & 12 & $-2^{* * *}$ \\
Exam Preparation Course (\%) & 54 & 52 & $3^{* * *}$ \\
Observations & & & \\
\hline \hline
\end{tabular}

Surprisingly, when looking to the whole sample values (Table 2) separately between pre-AA years and post-AA ones, the two periods show a significant difference in public high school students (i.e., eligible students) in an opposite way from what we expected. The sample of the pre-INCLUSP years contains an average of 35 percent of public high school applicants and the one following the AA, from 2008 to 2014, has an average of 24 percent of this type of student. This drop indicates that the policy probably did not cause an increase of eligible applicants in FUVEST's exam and that its impact was probably not due to the change in the pool of applicants.

We verified this hypothesis in Section 4, using the dataset of students which applied for UNICAMP's vestibular, one of USP's main competitor. The goal with this second dataset was to search for the existence of confounding factors in the composition of FUVEST's applicants - such as a possible general increase of applicants from public high school in public universities, which could affect our results. Thus, we compared the profile of the applicants of the two universities, which we will detail in Section 4.

When looking into Tables 3 and 4, we can see that the drop of public school applicants between years happened at the beginning of INCLUSP years. Between 2006 and 2008 there was a drop of 12 percentage points of this type of applicants, with the rate going 
from 38 percent to 26 percent. We also find out that the 26 percent rate was roughly constant from 2008 to the final year of our sample. In Table 4, we can see that this rate went from 24 percent in 2012 to 25 percent in 2014 . Therefore, this indicates that not only INCLUSP probably did not have a secondary effect of raising the rate of public school applicants - which are the eligible students to the policy -, but either INCLUSP or another unknown factor caused a significant drop in this rate throughout the years.

Table 3 - Descriptive Statistics (2006 - 2008)

\begin{tabular}{lccc}
\hline \hline & Pre AA & Post AA & Difference \\
Public High School (\%) & 38 & 26 & $12^{* * *}$ \\
Visible Minority (\%) & 20 & 16 & $4^{* * *}$ \\
Female (\%) & 55 & 54 & $1^{* * *}$ \\
Technical High School (\%) & 8 & 5 & $2^{* * *}$ \\
Age & 19.50 & 19.11 & $0.39^{* * *}$ \\
Mother without HS Degree (\%) & 31 & 20 & $12^{* * *}$ \\
Mother with HS Degree (\%) & 22 & 23 & $-0^{* * *}$ \\
Mother with Univ. Degree (\%) & 38 & 48 & $-11^{* * *}$ \\
Father without HS Degree (\%) & 31 & 19 & $12^{* * *}$ \\
Father with HS Degree (\%) & 19 & 21 & $-2^{* * *}$ \\
Father with Univ. Degree (\%) & 40 & 49 & $-8^{* * *}$ \\
Previous University Attendance (\%) & 10 & 12 & $-2^{* * *}$ \\
Exam Preparation Course (\%) & 54 & 54 & 0 \\
Observations & & & 1771715 \\
\hline \hline
\end{tabular}

Table 4 - Descriptive Statistics (2012 - 2014)

\begin{tabular}{lccl}
\hline \hline & Pre AA & Post AA & Difference \\
Public High School (\%) & 24 & 25 & $-1^{* * *}$ \\
Visible Minority (\%) & 15 & 17 & $-2^{* * *}$ \\
Female (\%) & 54 & 54 & -0 \\
Technical High School (\%) & 6 & 6 & $0^{*}$ \\
Age & 18.80 & 18.75 & $6^{* * *}$ \\
Mother without HS Degree (\%) & 15 & 15 & 0 \\
Mother with HS Degree (\%) & 23 & 23 & $0^{*}$ \\
Mother with Univ. Degree (\%) & 53 & 54 & $-1^{* * *}$ \\
Father without HS Degree (\%) & 15 & 19 & $-4^{* * *}$ \\
Father with HS Degree (\%) & 23 & 22 & $1^{* * *}$ \\
Father with Univ. Degree (\%) & 50 & 51 & 0 \\
Previous University Attendance (\%) & 13 & 13 & -0 \\
Exam Preparation Course (\%) & 55 & 46 & $10^{* * *}$ \\
Observations & & & \\
\hline \hline
\end{tabular}


Our second group of interest, the black, pardo and indigenous students (PPI) does not show the same difference: from Table 2 we can see that the rate of eligible students for the racial criteria of the program was the same, on average, for the two periods, resulting in around 16 percent of the sample. This also indicates that INCLUSP probably did not have an effect of raising the rate of self-declared PPI applicants to the exam. However, this result illustrates how the access to public education in Brazil is unequal between racial groups, once the proportion of self-declared black, pardo and indigenous in the country as a whole sum over 50 percent of the population. When looking at Tables 3 and 4, however, we can see that there was an oscillation of this rate throughout the years: in 2006 there was around 20 percent of PPI students, and this rate dropped to 16 percent in 2008. Between 2012 and 2014, however, there was a slight increase in this rate, going from 15 to 17 percent in 2014. This indicates that the inclusion of the racial bonus in 2014 might have affected the percentage of PPI applicants. However, since we do not have information on the subsequent years of this database, we cannot affirm that.

From Tables 2-4 it is also possible to notice that the level of parental education changed over time, being significantly higher in the second period (2008-2014) than in the first one. Table 2 shows that the rate of students with mothers with a university degree rose around 13 percentage points between the two periods, and this increase is observed in Tables 3 and 4 also. Finally, the rate of students that attended a preparation course to take the exam rose from 51 to 55 percent between the two periods. In Section 4, we will present the methodology for estimating the impacts of INCLUSP on the access to USP, as well as the results. 


\section{The impacts of INCLUSP on university ac-}

\section{cess}

To analyze the effect of INCLUSP on the university's access, we 1) measured the change of the applicants' probability of access to USP according to their individual characteristics using a differences-in-differences approach, 2) compared the characteristics of successful applicants who would not have been approved without the program (displacing) and students who lost their places at USP due to INCLUSP (displaced), and 3) analyzed potential behavioral effects, noting if they were responsible for a possible change in the composition of the applicants.

\subsection{Individual Probability of Admission}

\subsubsection{The differences-in-differences model}

For the first step, we used a differences-in-differences estimation to search for changes in the students' probability of being accepted, enrolling, and graduating at the university. Here, the methodological strategy is similar to that used by Estevan, Gall and Morin (2019). The goal was to identify how the implementation of the AA changed the chances of eligible applicants to enter USP. Naturally, the treatment group is the eligible applicants, and the control group is the ineligible ones. We used the following equation:

$$
\begin{aligned}
A_{i, m, t}= & \gamma+\rho P_{i}+\pi V_{i}+\delta\left(I_{i}^{\text {post }} * P_{i}\right)+\beta\left(I_{i}^{\text {post }} * V_{i}\right) \\
& +\eta\left(I_{i}^{\text {post }} * P_{i} * V_{i}\right)+\phi X_{i}+\alpha_{m}+\theta_{t}+\mu_{i, m, t}
\end{aligned}
$$

Where $A_{i, c, t}$ is a dummy variable that indicates whether the applicant $i$, applying for major $m$ in year $t$ was approved in the exam. $I_{i}^{\text {post }}$ is a dummy variable for enrollment on the exam after the policy year analyzed, $P_{i}$ is a dummy variable of eligibility to the public school bonus and $V_{i}$ indicates whether the student is eligible for the selfdeclared visible minority bonus. Also, we included the $X_{i}$ vector of control variables such as socioeconomic characteristics, gender, parental education, among others. Here, it is relevant to mention that since the control parental education is highly correlated with socioeconomic background in Brazil - and therefore eligibility to the policy here evaluated -, the inclusion of this specific control helps mitigating possible identification problems. Finally, we added $\alpha_{m}$ and $\theta_{t}$ fixed effects of major choice and year, as well as the robust standard error $\mu_{i, m, t}$. 
It is important to emphasize that we included the variable $V_{i}$ only for the equations where we evaluated the inclusion of the racial criteria. ${ }^{1}$. Also, we ran this equation many times, considering different years as the post-AA year, to capture the effect of different bonus sizes, as we mentioned before.

Therefore, the leading coefficient of interest is $\delta$, which identifies the impact of INCLUSP on changing the likelihood that the eligible applicant will get into USP. When also evaluating the inclusion of the racial bonus, the coefficients of interest become $\delta$ and $\eta$, where the second identifies the impact of an increase in the admission probability associated with the inclusion of racial criteria in the INCLUSP. Also, we can observe the $\beta$ coefficient, which identifies the change in the likelihood of a visible minority applicant that comes from a private high school in university access.

In this first exercise, we also looked for the changes in the probability of enrolling in the university due to the bonus and for the changes in the likelihood of graduating once you enrolled in an undergraduate course. To do that, we considered Equation (4.1) with different dependent variables. To look for changes in the probability of enrolling to the university, we used a dummy dependent variable which is equal to one when the student did enroll for the major she was admitted to, and zero when the applicant was not invited to the university or got in and rejected the spot. To look for changes in the probability of graduating at the university, the dependent variable equals one when the enrolled student did finish her course, and zero when she did not graduate.

In this step, we were able to verify if the probability of graduating was affected by the policy. Since we had limited information on this variable, we did this using only the years of 2008, and 2009 as the years post-policy. Therefore, the bonus given to these students was $3 \%$, meaning that this analysis is limited in that sense.

In addition to that, we did the same exercise, using similar equations, to 1) verify the effect of INCLUSP in the change in the probability of an enrolled student finish the course in the ideal period of time and 2) check if the effect was different when considering only the students who were competing for spots on the $50 \%$ most competitive majors. The results for these two last models are at Appendix A, at Tables 27 and 28.

Finally, to observe the results from a more aggregated perspective, we used Equation (4.2) below, using the whole sample and interactions between different years and a public high

$1 \quad$ As already exposed, between 2013 and 2014 changes in the INCLUSP program were the increase of the maximum bonus obtained by a public school student from $12.5 \%$ to $20 \%$, in addition to the inclusion of the $5 \%$ bonus for applicants from the public school and self-declared blacks, browns or indigenous. Thus, in 2014, the maximum bonus obtained by an applicant eligible to INCLUSP was $25 \%$. 
school dummy.

$$
\begin{aligned}
A_{i, m, t}= & \gamma+\rho P_{i}+\pi V_{i}+\delta_{0}\left(I_{i}^{08} * P_{i}\right)+\delta_{1}\left(I_{i}^{09} * P_{i}\right)+\delta_{2}\left(I_{i}^{12} * V_{i}\right)+\delta_{3}\left(I_{i}^{13} * P_{i}\right) \\
& +\delta_{4}\left(I_{i}^{14} * P_{i}\right)+\beta\left(I_{i}^{14} * V_{i}\right)+\phi X_{i}+\alpha_{m}+\theta_{t}+\mu_{i, m, t}
\end{aligned}
$$

Where $\delta_{0}, \delta_{1}, \delta_{2}, \delta_{3}$ and $\delta_{4}$ are the coefficients of interest, which indicate the effect of each of these years of the policy (with different bonus magnitudes) on the probability of acceptance of an eligible student. Since 2014 is the only year that had a racial bonus, the $\beta$ coefficient shows the effect on the visible minority students' acceptance probability.

As an alternative to looking into INCLUSP's effects from an aggregate perspective, we used a similar equation to Equation (4.1), where the treatment variable is continuous and varies according to the year of the policy. Specifically, instead of using a dummy variable that equals one when the observation is from a year post-AA, we used a continuous variable that equals the amount of the bonus of each year: it is equal to 0.03 for observations from 2008, 0.12 for the ones from 2009, and so on. Hence, we arrived at the following equation:

$$
A_{i, m, t}=\gamma+\rho P_{i}+\pi V_{i}+\delta\left(T_{i} * P_{i}\right)+\phi X_{i}+\alpha_{m}+\theta_{t}+\mu_{i, m, t}
$$

Where $T_{i}$ is the continuous treatment variable, the coefficient of interest is $\delta$, and the rest of the variables are the same as in Equation (4.1). The results from Equations (4.1) - (4.3) will be at Section 4.1.3. 


\subsubsection{Parallel Trends Assumption}

One of the main assumptions of the difference-in-differences model is the Parallel Trends Assumption. It requires that the difference in the outcomes between the treatment and the control groups before the policy or the intervention is constant over time. In this study, this means that both the eligible and the ineligible groups should have a constant difference in the probability of admission between the years before INCLUSP started.

To investigate if this assumption holds in our dataset, we ran Equation (4.1) for the years pre-AA (2000 to 2006) and observed the $\delta$ coefficient. The idea is that even though INCLUSP did not exist before 2007, if there was a difference in admission probability of the two groups across time (i.e., a violation of the parallel trend assumption), we would be able to identify this by observing different values of the $\delta$ coefficient throughout the years. Hence, we simulated a differences-in-differences model even though there was no policy between 2000 and 2006 to check for this assumption.

To observe the trend year by year, we ran Equation (4.1) for every pair of years from 2000 to 2006: we started running the model considering 2001 as the post-AA year and 2000 as the pre-AA year, then we regressed 2002 against 2001 and continued the same logic until 2006 and 2005. Tables 5 and 6 show the results for years immediately before the policy, from 2004 to $2006 .^{2}$

Table 5 - Admission Probability without INCLUSP (2004 - 2005)

\begin{tabular}{lccccc}
\hline \hline & $(1)$ & $(2)$ & $(3)$ & $(4)$ & $(5)$ \\
Public High School & $-0.037^{* * *}$ & $-0.037^{* * *}$ & $-0.037^{* * *}$ & $-0.014^{* * *}$ & $-0.025^{* * *}$ \\
Visible Minority & $(0.002)$ & $(0.002)$ & $(0.002)$ & $(0.002)$ & $(0.002)$ \\
& $-0.024^{* * *}$ & $-0.025^{* * *}$ & $-0.027^{* * *}$ & $-0.017^{* * *}$ & $-0.019^{* * *}$ \\
Public HS x AA Years & $(0.003)$ & $(0.003)$ & $(0.003)$ & $(0.003)$ & $(0.003)$ \\
& $-0.010^{* * *}$ & $-0.009^{* * *}$ & $-0.008^{* * *}$ & $-0.006^{* *}$ & $-0.008^{* * *}$ \\
Visible Minority x Public HS & $(0.002)$ & $(0.003)$ & $(0.003)$ & $(0.003)$ & $(0.003)$ \\
& $-0.006^{*}$ & -0.005 & -0.000 & -0.001 & 0.001 \\
Visible Minority x AA Years & $(0.003)$ & $(0.004)$ & $(0.004)$ & $(0.004)$ & $(0.004)$ \\
& -0.003 & -0.002 & -0.002 & -0.001 & -0.001 \\
Visible Minority x Public HS x AA Years & $(0.003)$ & $(0.005)$ & $(0.005)$ & $(0.005)$ & $(0.004)$ \\
& & -0.002 & -0.002 & -0.003 & -0.004 \\
Year Fixed Effects & Yes & $(0.006)$ & $(0.006)$ & $(0.006)$ & $(0.006)$ \\
Age and Gender Controls & No & No & Yes & Yes & Yes \\
Parental Education Controls & No & No & No & Yes & Yes \\
University Experience Control & No & No & Yes & Yes & Yes \\
Program Fixed Effects & No & No & No & No & Yes \\
& & & & & \\
\hline Observations & 252,220 & 252,220 & 252,220 & 249,944 & 249,944 \\
R-squared & 0.010 & 0.010 & 0.021 & 0.026 & 0.067 \\
\hline \hline
\end{tabular}

2 The results from the equations of the previous years are at Appendix A. 
Looking at the results, we see that the $\delta$ coefficient is significant and measures -0.008 in Table 5 and -0.011 in Table 6, in Specification (5), the one with the complete set of control variables. Therefore, between those years, the fictional eligible applicants would have a lower probability of admission of 1.1 and 0.8 p.p., respectively. Even though these two numbers are not equal to zero - which we require to state that the parallel trend assumption holds -, the fact that these values are similar and negative is relevant.

The similarity between these two coefficients suggests that the ineligible students had a roughly constant change in the probability of admission on the years before the implementation of INCLUSP. Even if we look to the results from the other equations - in Appendix A-, we see that the $\delta$ coefficients are not very different, oscillate around zero, positive and negative numbers, and are always minimal. Besides, when looking at Specification (5) at Tables 5 and 6 , we can see all of them are negative and significant. This suggests that the admission probability of eligible students was either stable or decreasing over the years before INCLUSP, which does not harm our analysis.

Table 6 - Admission Probability without INCLUSP (2005 - 2006)

\begin{tabular}{lccccc}
\hline \hline & $(1)$ & $(2)$ & $(3)$ & $(4)$ & $(5)$ \\
Public High School & $-0.047^{* * *}$ & $-0.047^{* * *}$ & $-0.046^{* * *}$ & $-0.019^{* * *}$ & $-0.030^{* * *}$ \\
& $(0.002)$ & $(0.002)$ & $(0.002)$ & $(0.002)$ & $(0.002)$ \\
Visible Minority & $-0.028^{* * *}$ & $-0.027^{* * *}$ & $-0.029^{* * *}$ & $-0.018^{* * *}$ & $-0.018^{* * *}$ \\
& $(0.003)$ & $(0.003)$ & $(0.003)$ & $(0.003)$ & $(0.003)$ \\
Public HS x AA Years & $-0.011^{* * *}$ & $-0.011^{* * *}$ & $-0.012^{* * *}$ & $-0.011^{* * *}$ & $-0.011^{* * *}$ \\
& $(0.002)$ & $(0.003)$ & $(0.003)$ & $(0.003)$ & $(0.003)$ \\
Visible Minority x Public HS & $-0.006^{* *}$ & -0.007 & -0.002 & -0.004 & -0.003 \\
& $(0.003)$ & $(0.004)$ & $(0.004)$ & $(0.004)$ & $(0.004)$ \\
Visible Minority x AA Years & 0.003 & 0.001 & 0.001 & 0.001 & -0.002 \\
& $(0.003)$ & $(0.005)$ & $(0.004)$ & $(0.004)$ & $(0.004)$ \\
Visible Minority x Public HS x AA Years & & 0.002 & 0.002 & 0.001 & 0.005 \\
& & $(0.006)$ & $(0.006)$ & $(0.006)$ & $(0.006)$ \\
Year Fixed Effects & Yes & Yes & Yes & Yes & Yes \\
Age and Gender Controls & No & No & Yes & Yes & Yes \\
Parental Education Controls & No & No & No & Yes & Yes \\
University Experience Control & No & No & Yes & Yes & Yes \\
Program Fixed Effects & No & No & No & No & Yes \\
& & & & & \\
\hline Observations & 263,203 & 263,203 & 263,203 & 260,711 & 260,711 \\
R-squared & 0.014 & 0.014 & 0.025 & 0.030 & 0.071 \\
\hline \hline
\end{tabular}

When performing Equation (4.2) for the whole sample pre-AA (using every year from 2000 to 2006), we reached some similar results, which are in Table 7 below. The $\delta$ coefficients from different years, although being different from zero, are very small when compared to the "Public High School" coefficient. This coefficient implies that before 2001, the public high school students had a 3.8 percentage points lower probability of admission at USP than the private high school applicants. Looking at Specification (4) of Table 7 we can see that the public high school students from both years 2001 and 2005 had an admission 
probability only 0.6 p.p. higher, even though this coefficient oscillated in the years between them. This suggests that in the year immediately before INCLUSP the public high school students faced a roughly constant probability of admission at USP.

However, we performed an F-test between the $\delta$ coefficients and were able to reject the Ho hypothesis at the $1 \%$ level for both the coefficients being equal to zero and being equal between themselves (the p-value being equal to 0.000 in both cases). Therefore, we cannot affirm that these coefficients were statistically constant across years. Even though the Parallel Trends Assumption does not hold expectedly for our dataset, the fact that the coefficient of interest oscillates around zero and that in the last two years before the policy the probability of access for eligible students was decreasing with time indicates that the results from Section 4.1.3 are likely to be robust. Furthermore, the fact that the $\delta$ coefficients found in Tables 5 and 6 are negative suggests that this decreasing trend might mitigate the effect of the policy, which possibly would be even higher in a scenario where the trends were parallel.

Table 7 - Year Dummies without INCLUSP (2000 - 2006)

\begin{tabular}{lcccc}
\hline & $(1)$ & $(2)$ & $(3)$ & $(4)$ \\
Public High School & & & & \\
& $-0.034^{* * *}$ & $-0.034^{* * *}$ & $-0.023^{* * *}$ & $-0.038^{* * *}$ \\
Visible Minority & $(0.002)$ & $(0.002)$ & $(0.002)$ & $(0.002)$ \\
& $-0.025^{* * *}$ & $-0.025^{* * *}$ & $-0.017^{* * *}$ & $-0.018^{* * *}$ \\
Public High School * 2001 & $(0.001)$ & $(0.001)$ & $(0.001)$ & $(0.001)$ \\
& $-0.007^{* * *}$ & $-0.005^{* *}$ & $0.005^{* *}$ & $0.006^{* *}$ \\
Public High School * 2002 & $(0.002)$ & $(0.002)$ & $(0.002)$ & $(0.002)$ \\
& $-0.008^{* * *}$ & $-0.006^{* * *}$ & $0.005^{* *}$ & $0.015^{* * *}$ \\
Public High School * 2003 & $(0.002)$ & $(0.002)$ & $(0.002)$ & $(0.002)$ \\
& $-0.006^{* *}$ & $-0.004^{*}$ & $0.007^{* * *}$ & $0.012^{* * *}$ \\
Public High School * 2004 & $(0.002)$ & $(0.002)$ & $(0.002)$ & $(0.002)$ \\
& $-0.005^{* *}$ & $-0.004^{*}$ & $0.007^{* * *}$ & $0.011^{* * *}$ \\
Public High School * 2005 & $(0.002)$ & $(0.002)$ & $(0.002)$ & $(0.002)$ \\
& $-0.016^{* * *}$ & $-0.013^{* * *}$ & -0.000 & $0.006^{* *}$ \\
Public High School * 2006 & $(0.002)$ & $(0.002)$ & $(0.002)$ & $(0.002)$ \\
& $-0.026^{* * *}$ & $-0.024^{* * *}$ & $-0.010^{* * *}$ & -0.001 \\
Year Fixed Effects & $(0.002)$ & $(0.002)$ & $(0.002)$ & $(0.002)$ \\
Age and Gender Controls & Yes & Yes & Yes & Yes \\
Parental Education Controls & No & Yes & Yes & Yes \\
University Experience Controls & No & No & Yes & Yes \\
Program Fixed Effects & No & No & Yes & Yes \\
\hline$F$-tests & No & No & No & Yes \\
$H_{0}:$ Public High School x Year $=0(p-v a l u e)$ & - & & & \\
$H_{0}:$ Public High School x Year $=\delta(p-v a l u e) ~$ & - & - & - & 0.000 \\
\hline Observations & 842,570 & 842,570 & 833,656 & 833,656 \\
R-squared & 0.009 & 0.020 & 0.025 & 0.055 \\
\hline \hline
\end{tabular}




\subsubsection{Results}

Tables 8 to 12 present the results of the main estimations, the difference-in-differences model, where the dependent variables are the admission dummy, the enrollment dummy and the graduation dummy. Tables 13 and 14 bring the results from equations (4.2) and (4.3), which are the one with the full set observations and dummies for each year, and the one with the continuous treatment variable. In this section, we expose the most relevant tables, but all of the results from every equation are in Appendix A. We found that, in general, $\delta$ - referred to as the "Public HS x AA Year" coefficient - is positive and significant for every estimation. This implies that there was an increase in the probability of eligible students being accepted, enrolling and graduating at USP after the implementation of the policy. Looking carefully into the coefficients, we reach some interesting conclusions.

Table 8 - Admission and Affirmative Action (2006 - 2008)

\begin{tabular}{lccccc}
\hline \hline & $(1)$ & $(2)$ & $(3)$ & $(4)$ & $(5)$ \\
Public High School & $-0.056^{* * *}$ & $-0.058^{* * *}$ & $-0.058^{* * *}$ & $-0.031^{* * *}$ & $-0.042^{* * *}$ \\
& $(0.002)$ & $(0.002)$ & $(0.002)$ & $(0.002)$ & $(0.002)$ \\
Visible Minority & $-0.019^{* * *}$ & $-0.026^{* * *}$ & $-0.028^{* * *}$ & $-0.017^{* * *}$ & $-0.021^{* * *}$ \\
& $(0.003)$ & $(0.003)$ & $(0.003)$ & $(0.003)$ & $(0.003)$ \\
Public HS x AA Years & $0.035^{* * *}$ & $0.040^{* * *}$ & $0.036^{* * *}$ & $0.032^{* * *}$ & $0.024^{* * *}$ \\
& $(0.003)$ & $(0.003)$ & $(0.003)$ & $(0.003)$ & $(0.003)$ \\
Visible Minority x Public HS & $-0.015^{* * *}$ & -0.005 & -0.001 & -0.002 & 0.002 \\
& $(0.003)$ & $(0.004)$ & $(0.004)$ & $(0.004)$ & $(0.004)$ \\
Visible Minority x AA Years & -0.001 & $0.012^{* *}$ & $0.011^{* *}$ & $0.009^{* *}$ & $0.009^{* *}$ \\
& $(0.003)$ & $(0.005)$ & $(0.005)$ & $(0.005)$ & $(0.004)$ \\
Visible Minority x Public HS x AA Years & & $-0.022^{* * *}$ & $-0.022^{* * *}$ & $-0.020^{* * *}$ & $-0.021^{* * *}$ \\
& & $(0.006)$ & $(0.006)$ & $(0.006)$ & $(0.006)$ \\
Year Fixed Effects & Yes & Yes & Yes & Yes & Yes \\
Age and Gender Controls & No & No & Yes & Yes & Yes \\
Parental Education Controls & No & No & No & Yes & Yes \\
University Experience Control & No & No & Yes & Yes & Yes \\
Program Fixed Effects & No & No & No & No & Yes \\
& & & & & \\
\hline Observations & 262,827 & 262,827 & 262,827 & 260,679 & 260,679 \\
R-squared & 0.010 & 0.010 & 0.022 & 0.027 & 0.076 \\
\hline \hline
\end{tabular}

Table 8 shows the results of INCLUSP's impact in its first years, considering the 2008 outcomes in comparison with the 2006 results. Specification (5), with the full set of controls, shows that before the AA a public high school student was about 4.2 percentage points less likely to get into USP than a private high school student. At the same time, the $\delta$ coefficient - "Public HS x AA Years" - for this first estimation at Specification (5) indicates that after the policy the group of eligible students had an increase of 2.4 percentage points of getting into USP. In other words, after only one year of the policy implementation the probability of an eligible applicant getting into USP increased 2.4 percentage points, lowering the disadvantage of a public high school student to a private high school one to 1.8 percentage points. This is a relevant result, especially since the INCLUSP maximum 
bonus in 2008 was only $3 \%$ and the admission rate in 2008 was 11.3 percent.

In this first estimation, even though the 2008 bonus did not target visible minority students (PPI), the group of self-declared PPI students that attended both private and public high school had an increase in the admission probability of 0.9 percentage points in comparison to the similar students that took the exam in 2006. On the other hand, the PPI students that did go to public high school (i.e., eligible PPI students), still faced the same disadvantage in 2008 that they did in 2006. Therefore, this indicates that in the first year of the policy the majority of the benefited students were white eligible applicants.

The net disadvantage that the eligible students still faced in 2008 seems to have almost disappeared in 2009 when the maximum bonus of INCLUSP rose to $12 \%$. In the detailed results that are in Appendix A (Table 24), we can see that although the eligible students had a 4.1 p.p. lower probability of admittance to USP in 2006, this was almost fully compensated in 2009. That is because the $\delta$ coefficient has roughly the same magnitude, 3.9 p.p., which is relevant considering that the admission rate in 2009 was 13 percent. This suggests that after two years of the policy, the eligible students no longer faced a significant disadvantage in USP's exam in comparison to the private school students. Besides, the p-value from testing the null hypothesis $H_{0}: \rho+\delta=0$ in this estimation is equal to 0.288 , meaning that we cannot reject it at conventional signicant levels. However, this seems to be valid also only to white public school students. The PPI students that went to public high school still faced a 2.5 p.p. lower probability of admittance than their counterparts, similar to the disadvantage PPI students faced in 2006.

Table 9 - Admission and Affirmative Action (2004 - 2014)

\begin{tabular}{lccccc}
\hline \hline & $(1)$ & $(2)$ & $(3)$ & $(4)$ & $(5)$ \\
Public High School & $-0.046^{* * *}$ & $-0.048^{* * *}$ & $-0.049^{* * *}$ & $-0.024^{* * *}$ & $-0.029^{* * *}$ \\
& $(0.001)$ & $(0.001)$ & $(0.001)$ & $(0.001)$ & $(0.001)$ \\
Visible Minority & $-0.021^{* * *}$ & $-0.026^{* * *}$ & $-0.028^{* * *}$ & $-0.018^{* * *}$ & $-0.019^{* * *}$ \\
& $(0.002)$ & $(0.002)$ & $(0.002)$ & $(0.002)$ & $(0.002)$ \\
Public HS x AA Years & $0.048^{* * *}$ & $0.050^{* * *}$ & $0.041^{* * *}$ & $0.037^{* * *}$ & $0.026^{* * *}$ \\
& $(0.001)$ & $(0.002)$ & $(0.002)$ & $(0.002)$ & $(0.001)$ \\
Visible Minority x Public HS & $-0.014^{* * *}$ & $-0.006^{* *}$ & -0.001 & -0.002 & -0.000 \\
& $(0.002)$ & $(0.003)$ & $(0.003)$ & $(0.003)$ & $(0.003)$ \\
Visible Minority x AA Years & -0.000 & $0.006^{* * *}$ & $0.005^{* *}$ & $0.004^{*}$ & 0.002 \\
& $(0.002)$ & $(0.002)$ & $(0.002)$ & $(0.002)$ & $(0.002)$ \\
Visible Minority x Public HS x AA Years & & $-0.012^{* * *}$ & $-0.014^{* * *}$ & $-0.014^{* * *}$ & $-0.017^{* * *}$ \\
& & $(0.003)$ & $(0.003)$ & $(0.003)$ & $(0.003)$ \\
Year Fixed Effects & Yes & Yes & Yes & Yes & Yes \\
Age and Gender Controls & No & No & Yes & Yes & Yes \\
Parental Education Controls & No & No & No & Yes & Yes \\
University Experience Control & No & No & Yes & Yes & Yes \\
Program Fixed Effects & No & No & No & No & Yes \\
& \multicolumn{7}{c}{} & & \\
\hline Observations & $1,200,105$ & $1,200,105$ & $1,200,105$ & $1,178,666$ & $1,178,666$ \\
R-squared & 0.007 & 0.007 & 0.022 & 0.026 & 0.090 \\
\hline \hline
\end{tabular}


At the same time that the policy had significant results shortly after its implementation, it is interesting to see that its effect was not linearly increasing with the increase in the bonus throughout the years. Table 9 contains the most exhaustive analysis, with the results from Equation (4.1) considering the period 2004-2014. It is possible to see that in Specification (5), the effect of INCLUSP in the years post-policy is positive and significant, almost fully compensating in magnitude the disadvantage that the public school applicants faced before the policy. More specifically, when we consider the whole period, the public school students seem to face a disadvantage of 2.9 percentage points in comparison to private school students before the policy, and INCLUSP compensated this in an amount of 2.6 percentage points, which is relevant considering that the admission probability of this period was around 8.3 percent. This shows that while the program was able to decrease the admission probability gap between these two groups of students, even in years where the maximum bonus was significantly higher (e.g., 2014, where the maximum bonus was 25\%), this program corrected the gap (although the p-value from testing the null hypothesis $H_{0}$ : $\rho+\delta=0$ is 0.0093 ), without giving one of the groups a comparative advantage.

However, when looking at the visible minority bonus, the results show that, at least in the first year of this type of bonus (2014), it did not seem to affect the admission probability. Table 9 shows that the "Visible Minority x Public HS x AA Years" coefficient, in Specification (5), is negative and significant, indicating that these students still faced a 1.7 percentage points lower probability of being admitted even after the inclusion of the racial bonus. This shows that the positive effect of INCLUSP was directed mainly towards white public school applicants.

Tables 10 and 11 carry the results from Equation (4.1), where the dependent variable is a dummy for enrollment. Here we are trying to verify whether the impact of INCLUSP was different in the change of probability of admittance and enrollment in the university. Since we have limited data on the information of enrollment, we performed this analysis using only the years of 2006 - 2009. Table 10 suggests that the impact of the program on the enrollment of eligible students in 2008 was positive and significant, even though it did not fully compensate for the existent gap after one year of the policy. If in 2006 the public school students faced a 3.3 percentage points lower probability of enrollment, this probability decreased 2.3 p.p. with INCLUSP, and the remaining gap was one percentage point. However, differently from the previous equations, in the third year of the policy, 2009 , the program was able to compensate and give a small comparative advantage to public high school students.

Table 11 shows that the coefficient of interest in 2009 becomes 3.6 percentage points (positive and significant), meaning that the public high school students ended up with a 0.3 percentage point higher probability of enrolling in the university after three years of INCLUSP. Besides, the p-value for the null hypothesis $H_{0}: \rho+\delta=0$ is 0.069 , which 
Table 10 - Enrollment and Affirmative Action (2006 - 2008)

\begin{tabular}{lccccc}
\hline & $(1)$ & $(2)$ & $(3)$ & $(4)$ & $(5)$ \\
Public High School & $-0.041^{* * *}$ & $-0.043^{* * *}$ & $-0.044^{* * *}$ & $-0.024^{* * *}$ & $-0.033^{* * *}$ \\
& $(0.002)$ & $(0.002)$ & $(0.002)$ & $(0.002)$ & $(0.002)$ \\
Visible Minority & $-0.012^{* * *}$ & $-0.018^{* * *}$ & $-0.020^{* * *}$ & $-0.013^{* * *}$ & $-0.016^{* * *}$ \\
& $(0.002)$ & $(0.003)$ & $(0.003)$ & $(0.003)$ & $(0.003)$ \\
Public HS x AA Years & $0.038^{* * *}$ & $0.042^{* * *}$ & $0.039^{* * *}$ & $0.035^{* * *}$ & $0.023^{* * *}$ \\
& $(0.002)$ & $(0.002)$ & $(0.002)$ & $(0.002)$ & $(0.002)$ \\
Visible Minority x Public HS & $-0.017^{* * *}$ & $-0.007^{* *}$ & -0.004 & -0.004 & -0.001 \\
& $(0.003)$ & $(0.004)$ & $(0.004)$ & $(0.004)$ & $(0.004)$ \\
Visible Minority x AA Years & 0.004 & $0.016^{* * *}$ & $0.015^{* * *}$ & $0.014^{* * *}$ & $0.011^{* * *}$ \\
& $(0.003)$ & $(0.004)$ & $(0.004)$ & $(0.004)$ & $(0.004)$ \\
Visible Minority x Public HS x AA Years & & $-0.022^{* * *}$ & $-0.022^{* * *}$ & $-0.020^{* * *}$ & $-0.019^{* * *}$ \\
& & $(0.005)$ & $(0.005)$ & $(0.005)$ & $(0.005)$ \\
Year Fixed Effects & Yes & Yes & Yes & Yes & Yes \\
Age and Gender Controls & No & No & Yes & Yes & Yes \\
Parental Education Controls & No & No & No & Yes & Yes \\
University Experience Control & No & No & No & Yes & Yes \\
Program Fixed Effects & No & No & No & No & Yes \\
& & & & & \\
\hline Observations & 262,827 & 262,827 & 262,827 & 260,679 & 260,679 \\
R-squared & 0.006 & 0.006 & 0.019 & 0.022 & 0.066 \\
\hline \hline
\end{tabular}

suggests that the eligible group might have indeed ended up with a comparative advantage in the enrollment probability.

Looking at Table 12, which shows the impact of INCLUSP on the probability of the graduation rate, we find similar results. The policy, in this case, was able to compensate fully, after three years, the pre-existing gap between public and private high school students. Besides, the p-value from testing the null hypothesis $H_{0}: \rho+\delta=0$ is equal to 0.429 , which means that it could not be rejected. This is a very significant result, since it suggests that INCLUSP provided not only a short-term effect - the admission to the university - but also a long-term effect, equalizing the graduation rate between the public and private high school students.

The effect on the eligible PPI students (Visible Minority) appears to be negative in the enrollment and graduation probability. This means that the PPI students from public high school faced a lower likelihood of enrolling and graduating at USP after three years of the policy, and indicates a possible distortion from INCLUSP. On the other hand, it is important to emphasize that the racial variable is self-reported in our database, so all of the analysis considering this criterion should take this in consideration.

Another relevant variable to the results of this dissertation is the aplicant's major choice (Table 27, Appendix A). When running the same equation with the dependent variable being a dummy that equals 1 when the applicant selected one of the $50 \%$ more competitive majors, the results are significant. Looking at the coefficient of interest, we can see that the aggregate impact of INCLUSP on the admittance of eligible applicants on competitive 
Table 11 - Enrollment and Affirmative Action (2006 - 2009)

\begin{tabular}{lccccc}
\hline & $(1)$ & $(2)$ & $(3)$ & $(4)$ & $(5)$ \\
Public High School & $-0.040^{* * *}$ & $-0.043^{* * *}$ & $-0.045^{* * *}$ & $-0.025^{* * *}$ & $-0.033^{* * *}$ \\
& $(0.002)$ & $(0.002)$ & $(0.002)$ & $(0.002)$ & $(0.002)$ \\
Visible Minority & $-0.010^{* * *}$ & $-0.018^{* * *}$ & $-0.020^{* * *}$ & $-0.013^{* * *}$ & $-0.016^{* * *}$ \\
& $(0.002)$ & $(0.003)$ & $(0.003)$ & $(0.003)$ & $(0.003)$ \\
Public HS x AA Years & $0.052^{* * *}$ & $0.057^{* * *}$ & $0.051^{* * *}$ & $0.047^{* * *}$ & $0.036^{* * *}$ \\
& $(0.002)$ & $(0.002)$ & $(0.002)$ & $(0.002)$ & $(0.002)$ \\
Visible Minority x Public HS & $-0.020^{* * *}$ & $-0.007^{*}$ & -0.004 & -0.003 & -0.001 \\
& $(0.002)$ & $(0.004)$ & $(0.004)$ & $(0.004)$ & $(0.004)$ \\
Visible Minority x AA Years & $0.004^{*}$ & $0.016^{* * *}$ & $0.015^{* * *}$ & $0.014^{* * *}$ & $0.011^{* * *}$ \\
& $(0.002)$ & $(0.004)$ & $(0.004)$ & $(0.004)$ & $(0.004)$ \\
Visible Minority x Public HS x AA Years & & $-0.021^{* * *}$ & $-0.021^{* * *}$ & $-0.020^{* * *}$ & $-0.020^{* * *}$ \\
& & $(0.005)$ & $(0.005)$ & $(0.005)$ & $(0.005)$ \\
Year Fixed Effects & Yes & Yes & Yes & Yes & Yes \\
Age and Gender Controls & No & No & Yes & Yes & Yes \\
Parental Education Controls & No & No & No & Yes & Yes \\
University Experience Control & No & No & No & Yes & Yes \\
Program Fixed Effects & No & No & No & No & Yes \\
& & & & & \\
\hline Observations & 379,120 & 379,120 & 379,120 & 371,990 & 371,990 \\
R-squared & 0.004 & 0.005 & 0.018 & 0.021 & 0.059 \\
\hline \hline
\end{tabular}

majors was 1.3 percentage points, which is half the impact of the same period when considering all majors (Table 9). However, the same table suggests that the pre-existing gap for this analysis was 1 percentage point, meaning that the public high school students ended up with a 0.3 p. p. advantage after the implementation of the policy. This is very significant, since it shows that the policy was probably successful in promoting the inclusion of eligible applicant at all types of majors, and not only at the less competitive ones.

Finally, looking at Tables 13 and 14, we can see the aggregate impact of INCLUSP on the whole sample, and the effect from each year of the policy. Table 13 confirms that there was not a linear increase in the policy's impact with the rise of the bonus: the bonus changes that seem to have been most significant were the 2009 rise - where the maximum bonus rose from $3 \%$ to $12 \%$ - and 2014 one, where it went from $20 \%$ to $25 \%$. In these cases, the admission probability of an eligible student increased 3.8 and 2.2 percentage points, respectively. Also, the p-value from testing the null hypothesis $H_{0}: \rho+\delta_{4}=0$ is equal to 0.755 in this estimation, which means that the observed reduction in the gap is statistically significant. Table 13 confirms that the visible minority bonus was probably not significant after one year of the policy: its coefficient suggests a 0.2 p.p. decrease in the probability admission, but it is statistically not significant.

In conclusion, these results indicate that INCLUSP had a significant positive effect in the probability of an eligible student be admitted, enroll and graduate at USP. Besides, the magnitude of the impact varies according to the size of the bonus in a non-linear way, and the policy seems to have reached its redistributional objectives. 
Table 12 - Graduation and Affirmative Action (2006 - 2009)

\begin{tabular}{lccccc}
\hline & $(1)$ & $(2)$ & $(3)$ & $(4)$ & $(5)$ \\
Public High School & $-0.035^{* * *}$ & $-0.037^{* * *}$ & $-0.037^{* * *}$ & $-0.022^{* * *}$ & $-0.024^{* * *}$ \\
& $(0.001)$ & $(0.001)$ & $(0.001)$ & $(0.002)$ & $(0.002)$ \\
Visible Minority & $-0.011^{* * *}$ & $-0.017^{* * *}$ & $-0.018^{* * *}$ & $-0.012^{* * *}$ & $-0.013^{* * *}$ \\
& $(0.002)$ & $(0.003)$ & $(0.003)$ & $(0.003)$ & $(0.003)$ \\
Public HS x AA Years & $0.036^{* * *}$ & $0.039^{* * *}$ & $0.037^{* * *}$ & $0.034^{* * *}$ & $0.025^{* * *}$ \\
& $(0.002)$ & $(0.002)$ & $(0.002)$ & $(0.002)$ & $(0.002)$ \\
Visible Minority x Public HS & $-0.010^{* * *}$ & 0.000 & 0.001 & 0.001 & 0.002 \\
& $(0.002)$ & $(0.003)$ & $(0.003)$ & $(0.003)$ & $(0.003)$ \\
Visible Minority x AA Years & 0.002 & $0.012^{* * *}$ & $0.011^{* * *}$ & $0.010^{* * *}$ & $0.007^{* *}$ \\
& $(0.002)$ & $(0.003)$ & $(0.003)$ & $(0.003)$ & $(0.003)$ \\
Visible Minority x Public HS x AA Years & & $-0.017^{* * *}$ & $-0.017^{* * *}$ & $-0.016^{* * *}$ & $-0.014^{* * *}$ \\
& & $(0.004)$ & $(0.004)$ & $(0.004)$ & $(0.004)$ \\
Year Fixed Effects & Yes & Yes & Yes & Yes & Yes \\
Age and Gender Controls & No & No & Yes & Yes & Yes \\
Parental Education Controls & No & No & No & Yes & Yes \\
University Experience Control & No & No & No & Yes & Yes \\
Program Fixed Effects & No & No & No & No & Yes \\
& & & & & \\
\hline Observations & 379,120 & 379,120 & 379,120 & 371,990 & 371,990 \\
R-squared & 0.004 & 0.004 & 0.006 & 0.009 & 0.029 \\
\hline \hline
\end{tabular}

Table 13 - Year Dummies and Affirmative Action (2004 - 2014)

\begin{tabular}{|c|c|c|c|c|}
\hline & (1) & $(2)$ & (3) & (4) \\
\hline Public High School & $\begin{array}{c}-0.035 \text { *** } \\
(0.001)\end{array}$ & $\begin{array}{c}-0.039^{* * *} \\
(0.001)\end{array}$ & $\begin{array}{c}-0.016^{\text {*** }} \\
(0.001)\end{array}$ & $\begin{array}{c}-0.022^{* * *} \\
(0.001)\end{array}$ \\
\hline Visible Minority & $\begin{array}{c}-0.028^{* * *} \\
(0.001)\end{array}$ & $\begin{array}{c}-0.030^{* * *} \\
(0.001)\end{array}$ & $\begin{array}{c}-0.020^{* * *} \\
(0.001)\end{array}$ & $\begin{array}{c}-0.022^{* * *} \\
(0.001)\end{array}$ \\
\hline Public High School * 2008 & $\begin{array}{c}0.012^{* * *} \\
(0.002)\end{array}$ & $\begin{array}{c}0.010 * * * \\
(0.002)\end{array}$ & $\begin{array}{c}0.010^{* * *} \\
(0.002)\end{array}$ & $\begin{array}{c}0.001 \\
(0.002)\end{array}$ \\
\hline Public High School * 2009 & $\begin{array}{l}0.053^{* * *} \\
(0.002)\end{array}$ & $\begin{array}{l}0.045^{* * *} \\
(0.002)\end{array}$ & $\begin{array}{l}0.045^{* * *} \\
(0.002)\end{array}$ & $\begin{array}{l}0.038^{* * *} \\
(0.002)\end{array}$ \\
\hline Public High School * 2012 & $\begin{array}{l}0.037^{* * *} * \\
(0.002)\end{array}$ & $\begin{array}{l}0.029 * * * \\
(0.002)\end{array}$ & $\begin{array}{l}0.025 * * * \\
(0.002)\end{array}$ & $\begin{array}{l}0.010^{* * *} \\
(0.002)\end{array}$ \\
\hline Public High School * 2013 & $\begin{array}{l}0.033^{* * *} * \\
(0.002)\end{array}$ & $\begin{array}{l}0.025^{* * *} \\
(0.002)\end{array}$ & $\begin{array}{l}0.023^{* * *} * \\
(0.002)\end{array}$ & $\begin{array}{l}0.011^{* * *} \\
(0.002)\end{array}$ \\
\hline Public High School * 2014 & $\begin{array}{l}0.039^{* * *} \\
(0.002)\end{array}$ & $\begin{array}{l}0.032^{* * *} \\
(0.002)\end{array}$ & $\begin{array}{l}0.029^{* * *} \\
(0.002)\end{array}$ & $\begin{array}{l}0.022^{* * *} \\
(0.002)\end{array}$ \\
\hline Visible Minority $* 2014$ & $\begin{array}{l}-0.001 \\
(0.003)\end{array}$ & $\begin{array}{l}-0.002 \\
(0.003)\end{array}$ & $\begin{array}{l}-0.002 \\
(0.003)\end{array}$ & $\begin{array}{l}-0.002 \\
(0.002)\end{array}$ \\
\hline Year Fixed Effects & Yes & Yes & Yes & Yes \\
\hline Age and Gender Controls & No & Yes & Yes & Yes \\
\hline Parental Education Controls & No & No & Yes & Yes \\
\hline University Experience Controls & No & No & Yes & Yes \\
\hline Program Fixed Effects & No & No & No & Yes \\
\hline Observations & $1,200,105$ & $1,200,105$ & $1,178,666$ & $1,178,666$ \\
\hline R-squared & 0.006 & 0.022 & 0.026 & 0.090 \\
\hline
\end{tabular}


Table 14 - Continuous Treatment Variable and Affirmative Action (2004 - 2014)
(1)
(2)
(3)
(4)

Public High School

\begin{tabular}{cccc}
$-0.032^{* * *}$ & $-0.037^{* * *}$ & $-0.013^{* * *}$ & $-0.021^{* * *}$ \\
$(0.001)$ & $(0.001)$ & $(0.001)$ & $(0.001)$ \\
$-0.028^{* * *}$ & $-0.030^{* * *}$ & $-0.021^{* * *}$ & $-0.022^{* * *}$ \\
$(0.001)$ & $(0.001)$ & $(0.001)$ & $(0.001)$ \\
$0.187^{* * *}$ & $0.149^{* * *}$ & $0.133^{* * *}$ & $0.089^{* * *}$ \\
$(0.007)$ & $(0.007)$ & $(0.007)$ & $(0.007)$ \\
Yes & Yes & Yes & Yes \\
No & Yes & Yes & Yes \\
No & No & Yes & Yes \\
No & No & Yes & Yes \\
No & No & No & Yes \\
\hline $1,200,105$ & $1,200,105$ & $1,178,666$ & $1,178,666$ \\
0.006 & 0.022 & 0.026 & 0.090 \\
\hline \multicolumn{5}{c}{}
\end{tabular}

Visible Minority

Treatment

Year Fixed Effects

Age and Gender Controls

Parental Education Controls

University Experience Controls

Program Fixed Effects

Observations 


\subsection{Redistribution according to Socioeconomic Characteristics}

To complement our findings on the potential redistributive effect of INCLUSP, we compared the characteristics of the displacing and the displaced applicants in the years following the implementation of the program, according to the methodology used Bertrand, Hanna and Mullainathan (2010). ${ }^{3}$ As already discussed, displacing applicants are those who would not get into the university if INCLUSP did not exist, and the displaced ones are those who lost their places to eligible applicants.

In this second exercise, the objective was to identify the redistributive effect of INCLUSP, that is, to analyze if displacing students come from more disadvantaged families than the displaced ones. Since we have information on the number of places available for each major at USP per year and on the applicants' final score, we were able to correctly identify the displaced and the displacing applicants in our sample. By calculating the "original" scores of the applicants without the received bonus (considering the premium to be zero when the applicant was ineligible), we were able to rank the students and simulate an admission process in a scenario without INCLUSP. Therefore, we compared the actual results with the simulated ones and identified the displaced and the displacing students.

It is important to emphasize that in this exercise we considered only students that were invited in the first round of calls into USP - since there are several rounds of calls in USP's admission process. For methodological reasons, we could not replicate precisely the admission process and consider all the subsequent calls that happen. Also, we performed this exercise using the sample from the years when INCLUSP faced significant changes. Therefore, the years used were 2008 - the second year of the policy, where the bonus was 3\%-; 2009, when the maximum bonus rose to 12\%; 2012 and 2013 where this value went up to $15 \%$ and $20 \%$, respectively; and 2014 , when the premium rose to $25 \%$, with the addition of the racial criterion.

Tables 15 to 17 show the detailed characteristics of both the displaced and the displacing group. Table 15 brings the aggregate results from the whole sample, whereas tables 16 and 17 show the results from 2008 and 2014, respectively. The results for the exercise using the years 2009, 2012 and 2013 are in Appendix A. The main observed variables for the two groups of students were school type, race, gender, career choice, and parental education. Specifically, looking at the Public High School variable, it is possible to see that nearly all the displacing students came from the public school system, which we already expected.

In line with Estevan, Gall and Morin (2019), we found that the majority of the displacing students, which were benefited by the program, have lower parental education than the displaced ones. Considering the full sample, $64 \%$ of the displaced students' mothers had a

3 The authors conducted an exercise that estimated whether a quota AA at universities, aimed at benefiting lower caste individuals in India, affected the expected students. 
Table 15 - Descriptive Statistics of Displacing and Displaced Applicants (2008 - 2014)

\begin{tabular}{lccc}
\hline \hline & Displacing & Displaced & Difference \\
& & & \\
Public High School & 0.996 & 0.014 & $0.982^{* * *}$ \\
Visible Minority & 0.251 & 0.096 & $0.154^{* * *}$ \\
Female & 0.419 & 0.467 & $-0.048^{* * *}$ \\
Technical High School & 0.194 & 0.043 & $0.151^{* * *}$ \\
Age & 21.102 & 19.385 & $1.717^{* * *}$ \\
Mother without HS degree & 0.314 & 0.091 & $0.223^{* * *}$ \\
Mother with HS degree & 0.293 & 0.185 & $0.109^{* * *}$ \\
Mother with university degree & 0.315 & 0.637 & $-0.322^{* * *}$ \\
Father without HS degree & 0.310 & 0.099 & $0.211^{* * *}$ \\
Father with HS degree & 0.262 & 0.160 & $0.103^{* * *}$ \\
Father with university degree & 0.318 & 0.618 & $-0.300^{* * *}$ \\
Previous University Experience & 0.278 & 0.210 & $0.068^{* * *}$ \\
Exam Preparation Course & 0.795 & 0.615 & $0.179^{* * *}$ \\
& & & \\
\hline Observations & 3405 & 3405 & \\
\end{tabular}

Table 16 - Descriptive Statistics of Displacing and Displaced Applicants (2008)

\begin{tabular}{lccc}
\hline \hline & Displacing & Displaced & Difference \\
& & & \\
Public High School & 1.000 & 0.000 & 1.000 \\
Visible Minority & 0.208 & 0.116 & $0.092^{* * *}$ \\
Female & 0.462 & 0.483 & -0.021 \\
Technical High School & 0.172 & 0.055 & $0.116^{* * *}$ \\
Age & 21.422 & 19.459 & $1.963^{* * *}$ \\
Mother without HS degree & 0.354 & 0.095 & $0.259^{* * *}$ \\
Mother with HS degree & 0.248 & 0.232 & 0.016 \\
Mother with university degree & 0.325 & 0.551 & $-0.227^{* * *}$ \\
Father without HS degree & 0.372 & 0.111 & $0.261^{* * *}$ \\
Father with HS degree & 0.225 & 0.160 & $0.066^{*}$ \\
Father with university degree & 0.303 & 0.599 & $-0.296^{* * *}$ \\
Previous University Experience & 0.230 & 0.211 & 0.018 \\
Exam Preparation Course & 0.778 & 0.665 & $0.113^{* * *}$ \\
& & & \\
\hline Observations & 379 & 379 &
\end{tabular}

university degree, against $32 \%$ of the displacing students' mothers. Besides, this difference is higher in 2014 than in 2008: in the second year of the policy, 55\% of the displaced students had mothers with a university degree; in 2014 this rate rose to $66 \%$. On the other hand, the rate of displaced students whose fathers were university degree holders changed from $60 \%$ to $63 \%$. This indicates that not only the policy displaced students with higher parental education, but also that the increase of the bonus targeted students with even less privileges in terms of access to education. 
Table 17 - Descriptive Statistics of Displacing and Displaced Applicants (2014)

\begin{tabular}{lccc}
\hline \hline & Displacing & Displaced & Difference \\
& & & \\
Public High School & 0.997 & 0.020 & $0.977^{* * *}$ \\
Visible Minority & 0.305 & 0.102 & $0.203^{* * *}$ \\
Female & 0.408 & 0.459 & $-0.051^{*}$ \\
Technical High School & 0.192 & 0.042 & $0.149^{* * *}$ \\
Age & 21.181 & 19.275 & $1.906^{* * *}$ \\
Mother without HS degree & 0.298 & 0.087 & $0.211^{* * *}$ \\
Mother with HS degree & 0.305 & 0.161 & $0.143^{* * *}$ \\
Mother with university degree & 0.326 & 0.665 & $-0.339^{* * *}$ \\
Father without HS degree & 0.330 & 0.110 & $0.220^{* * *}$ \\
Father with HS degree & 0.266 & 0.146 & $0.119^{* * *}$ \\
Father with university degree & 0.322 & 0.632 & $-0.310^{* * *}$ \\
Previous University Experience & 0.288 & 0.209 & $0.079^{* * *}$ \\
Exam Preparation Course & 0.789 & 0.582 & $0.208^{* * *}$ \\
& & & \\
\hline Observations & 997 & 997 &
\end{tabular}

We also found that among the displacing candidates the proportion of visible minority students is much higher than among the displaced ones, even in the years when the racial bonus was not present in INCLUSP. Besides, although the last section indicated that the racial bonus did not show a significant impact on the access probability, this exercise suggests that the addition of this criterion did make a difference at the margin. From Tables 15 to 17 we can see that the proportion of self-declared PPI displacing students was around 25 percent throughout the whole period. However, when looking at the results from 2008 and 2014 separately, this rate increased from $21 \%$ to $31 \%$ between those years. This difference is significant, especially considering that the percentage of PPI students in the displaced sample went from $12 \%$ in 2008 to $10 \%$ in 2014, showing much more stability than in displacing group.

Finally, we are also able to observe possible imbalances arising from the program. From Table 15 we see that the rate of female displacing applicants is around $42 \%$, while the rate of displaced applicants is around 47\%. As observed in Bertrand et al. (2010), this may indicate an increase in gender inequality in the university due to the AA. Another possible imbalance is the possibility of white public school students becoming displaced after the inclusion of the racial bonus in the program. That is, if in the absence of the racial bonus white public high school students lost their places to visible minority public school students, this would put them in the displaced group. In Table 13, where the racial criterion was already present in the AA, we can see that this effect is almost inexistent only $2 \%$ of the displaced applicants were from the public school system. However, this shows that in affirmative actions where different students received different sizes of bonus, 
such as INCLUSP, this is a possible result.

With this exercise, we could see that besides increasing the access probability of eligible students - which we could observe at Section 4.1 -, INCLUSP was responsible for changing the composition of the admitted students significantly. Furthermore, we can see that with the increase in the bonus, more students were affected: in 2008, when the maximum bonus was equal to $3 \%, 379$ students from public high schools were positively affected by the policy. Six years later, in 2014 (where the maximum bonus was 25\%), this number increased by almost three times: at least 997 students from public high school were accepted to USP exclusively because of INCLUSP.

\subsection{Confounding Factors and Behavioral Effects}

To validate the analysis carried out in the first two stages of the methodology, we verified if the profile of the applicants changed significantly around the year of the policy implementation. Thus, we investigated if the observed results were due to confounding factors and if there was evidence of behavioral effects resulting from the creation of INCLUSP. In other words, we tried to identify possible changes in the pool of applicants resulting from the decision of the students to enroll or not in the admission exam. Since in this AA the most affected applicants are public high school students, our results would be affected if we found an increase in the rate of public school applicants after the policy implementation. As mentioned on Section 3, we used data from the Universidade Estadual de Campinas ${ }^{4}$ (UNICAMP), between 2003 and 2008, in comparison with the FUVEST data. Analyzing the percentage of public school applicants in the two universities over time, we found that the rate of USP's public school applicants seemed to have followed UNICAMP's proportion throughout the years.

Figure 1 indicates that not only the rate from both universities varied in a similar way, but also there was a decrease in the public school applicants rate from 2006 to 2008. Since the policy implementation happened in 2007, this suggests that INCLUSP did not stimulate an increase in public school applicants, and therefore, our results were not affected by this possible increase.

Also, we observed how the applicants from both universities of different characteristics such as gender and visible minority students - varied across time. Similarly to Figure 1, Figure 2 shows the rate of these two groups of students were very similar between 2003 and 2008 in both universities. This fact implies that there was not an external factor such as INCLUSP - that induced an increase of a specific type of applicant throughout the years.

4 In English, State University of Campinas. 


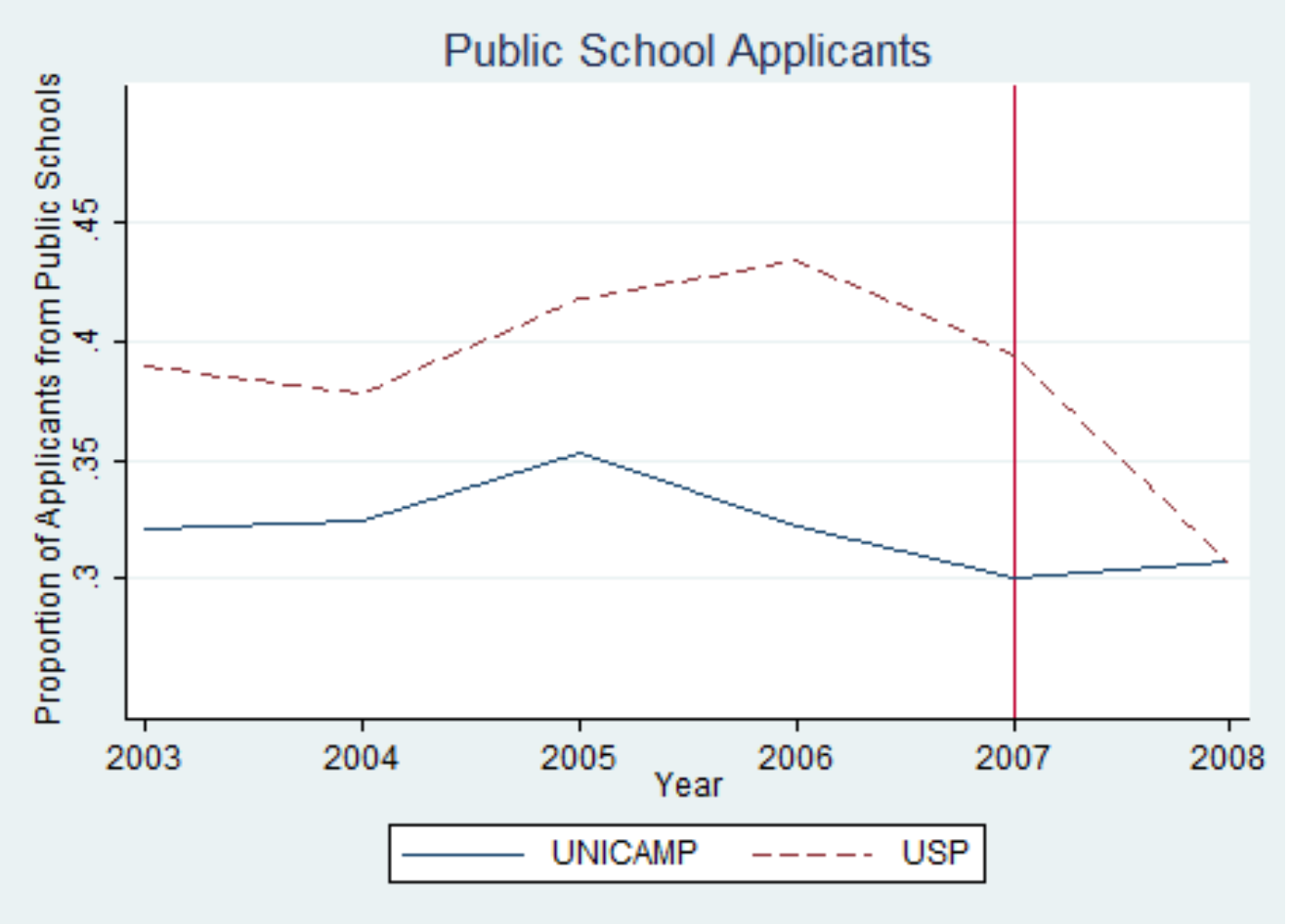

Figure 1 - Public School Aplicants at USP/UNICAMP per year
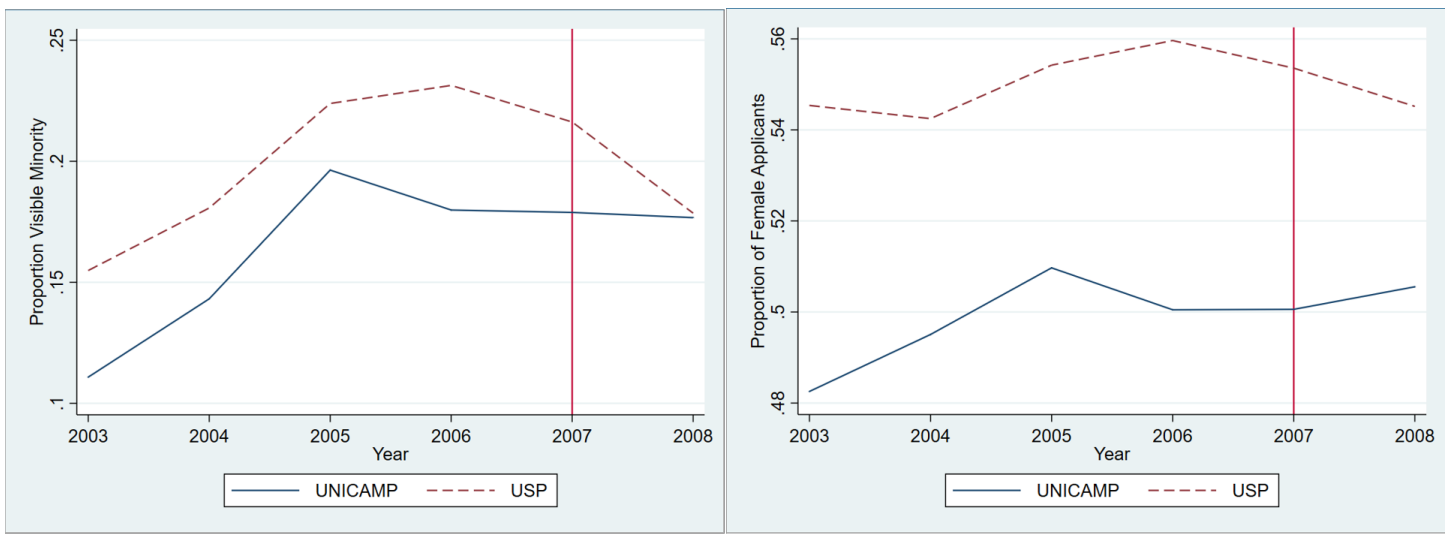

Figure 2 - Visible Minority and Female Applicants at USP/UNICAMP per year

In addition to verifying if there was indeed an increase in these type of students, we compared the descriptive statistics of the two groups of applicants, the eligible and the ineligible, before and after INCLUSP. As mentioned in Section 3 (Tables 2 to 4), the rate of public school students did not rise after the implementation of the program. Tables 18 and 19 show that the composition of the eligible and ineligible group of students oscillated similarly: both groups had an increase of 2 percentage points of self-declared visible minority students (PPI). Also, the rate of students who took a preparation course for the exam decreased in both groups, which indicates the absence of a possible increase of effort towards the test after the policy. On the other side, the eligible students had an increase of 8 percentage points in the rate of students with previous university experience. In general, the two groups seem to have changed in very similar ways, and only in a few of 
the observed characteristics. Therefore, the results suggest that there was not a behavioral composition effect and that the results found in sections 4.1 and 4.2 were not harmed in this way.

Table 18 - Eligible Applicants Descriptive Statistics (2000 - 2014)

\begin{tabular}{lccc}
\hline \hline & Pre AA & Post AA & Difference \\
& & & \\
Public High School (\%) & 0.29 & 0.32 & $-0.02^{* * *}$ \\
Visible Minority (\%) & 0.58 & 0.53 & $0.04^{* * *}$ \\
Female (\%) & 0.15 & 0.11 & $0.05^{* * *}$ \\
Technical High School (\%) & 20.88 & 20.93 & $-0.05^{* *}$ \\
Age & 0.58 & 0.41 & $0.17^{* * *}$ \\
Mother without HS Degree (\%) & 0.23 & 0.31 & $-0.08^{* * *}$ \\
Mother with HS Degree (\%) & 0.12 & 0.21 & $-0.10^{* * *}$ \\
Mother with Univ. Degree (\%) & 0.57 & 0.41 & $0.15^{* * *}$ \\
Father without HS Degree (\%) & 0.20 & 0.29 & $-0.09^{* * *}$ \\
Father with HS Degree (\%) & 0.14 & 0.19 & $-0.05^{* * *}$ \\
Father with Univ. Degree (\%) & 0.11 & 0.19 & $-0.08^{* * *}$ \\
Previous University Attendance (\%) & 0.67 & 0.64 & $0.03^{* * *}$ \\
Exam Preparation Course (\%) & 0.789 & 0.582 & $0.208^{* * *}$ \\
& & & \\
\hline \hline Observations & 329585 & 200144 & 529729
\end{tabular}

Table 19 - Ineligible Applicants Descriptive Statistics (2000 - 2014)

\begin{tabular}{lccc}
\hline \hline & Pre AA & Post AA & Difference \\
& & & \\
Public High School (\%) & 0.09 & 0.11 & $-0.01^{* * *}$ \\
Visible Minority (\%) & 0.53 & 0.54 & $-0.01^{* * *}$ \\
Female (\%) & 0.08 & 0.04 & $0.05^{* * *}$ \\
Technical High School (\%) & 18.84 & 18.33 & $0.51^{* * *}$ \\
Age & 0.17 & 0.09 & $0.08^{* * *}$ \\
Mother without HS Degree (\%) & 0.22 & 0.21 & $0.01^{* * *}$ \\
Mother with HS Degree (\%) & 0.50 & 0.61 & $-0.11^{* * *}$ \\
Mother with Univ. Degree (\%) & 0.16 & 0.10 & $0.06^{* * *}$ \\
Father without HS Degree (\%) & 0.17 & 0.19 & $-0.03^{* * *}$ \\
Father with HS Degree (\%) & 0.55 & 0.60 & $-0.04^{* * *}$ \\
Father with Univ. Degree (\%) & 0.11 & 0.10 & $0.01^{* * *}$ \\
Previous University Attendance (\%) & 0.56 & 0.49 & $0.07^{* * *}$ \\
Exam Preparation Course (\%) & 0.789 & 0.582 & $0.208^{* * *}$ \\
& & & \\
\hline \hline Observations & 512985 & 611220 & 1124205
\end{tabular}




\section{Conclusion}

In this masters thesis, we investigate the impact of INCLUSP - USP's bonus-based affirmative action created at 2007 - on the probability of admission, enrollment, and graduation of public and private high school students, by using a difference-in-differences method. Our results suggest that there was a positive effect on the three dependent variables for eligible students, i.e., students who fulfilled the criteria for being qualified for INCLUSP. If these students faced a disadvantage in the admission probability before the AA, this gap seems to have disappeared with the implementation of the policy. This is a significant result, once it implies that INCLUSP was successful in reducing the admission probability difference between public and private high school applicants to almost zero, and in some cases (such as the probability of graduation), the eligible applicants ended up with a small comparative advantage to the ineligible ones.

Besides, the affirmative action appears to be successful in the redistributing the spots among applicants, promoting an increase on the admission of more disadvantaged students, with lower socio-economic backgrounds. We identified this by simulating an admission process without the presence of the INCLUSP bonus and analyzing the characteristics from the displaced and displacing applicants due to the policy. Also, since USP's admittance exam, FUVEST, did not suffer any significant changes in the pool of applicants in the years around the implementation of the AA, the results seem to be robust. There was not an increase in the proportion of applicants coming from public high school, and the eligible and ineligible applicants' characteristics oscillated in similar ways across the years.

Overall, INCLUSP was successful in decreasing the probability admission gap between public and private high school graduates, with little to none distortion effects. Since bonus-based affirmative actions are not the most common in Brazilian universities, these findings become relevant to the design of affirmative action policies. 


\section{Bibliography}

AKHTARI, M.; BAU, N. Race-based affirmative action and student effort. Working Paper, 2016. 14

ASSUNçãO, J.; FERMAN, B. Does affirmative action enhance or undercut investmentincentives? evidence from quotas in brazilian public universities. Working Paper, 2015. 14

BERTRAND, M.; HANNA, R.; MULLAINATHAN, S. Affirmative action in education:evidence from engineering college admissions in india. Journal of Public Economics, v. 94, p. 16-29, 2010. 43

CARD, D.; KRUEGER, A. Would the elimination of affirmative action affect highlyqualified minority applicants? evidences from california and texas. Industrial and Labor Relations Review, v. 58, n. 3, 2005. 13

CARNAVALE, S. R. A. Socioeconomic status, race/ethnicity and selective collegeadmissions. A Century Foundation Paper, 2003. 12

CHAN, J.; EYSTER, E. Does banning affirmative action lower college student quality? The American Economic Review, v. 93, n. 3, p. 858-872, 2003. 13, 14

DAFLON, V.; JUNIOR, J. F.; CAMPOS, L. A. Ações afirmativas raciais no ensino superior público brasileiro: um panorama analítico. Cadernos de Pesquisa (Fundação Carlos Chagas), v. 43, n. 148, p. 302-347, 2013. 13, 14, 18

DICKSON, L. Does ending affirmative action in college admissions lower the percent of minority students applying to college? Economics of Education Review, v. 25, p. 109-119, 2006. 14

ESTEVAN, F.; GALL, T.; MORIN, L.-P. Redistribution without distortion: evidence froman affirmative action program at a large brazilian university. The Economic Journal, v. 129, n. 619 , p. $1220,2019.15,30,43$

FRANCIS, A.; TANNURI-PIANTO, M. E. The redistributive equity of affirmative action:exploring the role of race, socioeconomic status, and gender in college admissions. Economics of Education Review, v. 31, p. 45-55, 2012. 12

FRANCIS, A.; TANNURI-PIANTO, M. E. Using brazil's racial continuum to examinethe short-term effects of affirmative action in higher education. The Journal Of Human Resources, v. 47, n. 3, p. 754-784, 2012. 14

HINRICHS, P. The effects of affirmative action bans on college enrollment, educational attainment, and the demographic composition of universities. The Review of Economics and Statistics, v. 94, n. 3, p. 712-722, 2012. 14

IBGE. Características Étnico-raciais da população - um estudo das categorias declassicação de cor ou raça. 2008. Available at: < https://biblioteca.ibge.gov.br/visualizacao/livros/ liv63405.pdf >. 12

JUNIOR, A.; WALTENBERG, F. Políticas de cotas não raciais aumentam a admissão de pretos e pardos na universidade? Planejamento e Políticas Públicas, v. 44, 2015. 14 
MATOS, M. et al. O impacto do programa de inclusão social da universidade de são paulo no acesso de estudantes de escola pública ao ensino superior público gratuito. Revista Brasileira de Estudos Pedagógicos, v. 93, n. 235, p. 720-742, 2012. 13

OLIVEIRA, R. P. Da universalização do ensino fundamental ao desafio da qualidade:uma análise histórica. Educ. Soc. De Campinas,, v. 28, n. 100, 2007. 12

PIOTTO, D. A. C.; NOGUEIRA, M. A. Incluindo quem? Um exame de indicadores

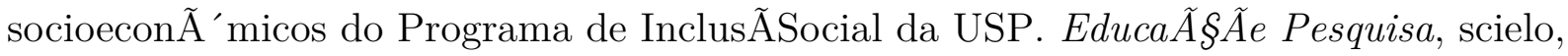
v. 42, p. 625 - 649, 09 2016. ISSN 1517-9702. Available at: <http://www.scielo.br/scielo. php?script $=$ sci_arttext\&pid $=\mathrm{S} 1517-97022016000300625 \& \mathrm{nrm}=\mathrm{iso}>.13$

ROTHSTEIN, J.; YOON, A. Affirmative action in law school admissions: what do racial preferences do? University of Chicago Law Review, v. 75, n. 2, 2008. 13

SANDER, H. R. A systemic analysis of affirmative action in american law schools. Stanford Law Review, v. 57, 2004. 13

ZAGO, N. Do acesso a permanencia no ensino superior: percursos de estudantes universitários de camadas populares. Revista Brasileira de Educação, v. 11, n. 32, 2006. 12 
Appendix 


\section{APPENDIX A - Tables}

Table 20 - Admission Probability without INCLUSP (2000 - 2001)

\begin{tabular}{lccccc}
\hline \hline & $(1)$ & $(2)$ & $(3)$ & $(4)$ & $(5)$ \\
Public High School & & & & \\
& & & \\
& $-0.035^{* * *}$ & $-0.034^{* * *}$ & $-0.036^{* * *}$ & $-0.023^{* * *}$ & $-0.036^{* * *}$ \\
Visible Minority & $(0.002)$ & $(0.002)$ & $(0.002)$ & $(0.002)$ & $(0.002)$ \\
& $-0.021^{* * *}$ & $-0.020^{* * *}$ & $-0.024^{* * *}$ & $-0.016^{* * *}$ & $-0.021^{* * *}$ \\
Public HS x AA Years & $(0.003)$ & $(0.004)$ & $(0.004)$ & $(0.004)$ & $(0.004)$ \\
& $-0.007^{* * *}$ & $-0.007^{* * *}$ & $-0.006^{* *}$ & -0.001 & -0.001 \\
Visible Minority x Public HS & $(0.002)$ & $(0.003)$ & $(0.003)$ & $(0.003)$ & $(0.003)$ \\
& 0.002 & 0.000 & 0.005 & -0.002 & -0.001 \\
Visible Minority x AA Years & $(0.004)$ & $(0.005)$ & $(0.005)$ & $(0.005)$ & $(0.005)$ \\
& -0.001 & -0.003 & -0.004 & -0.001 & -0.002 \\
Visible Minority x Public HS x AA Years & $(0.004)$ & $(0.006)$ & $(0.006)$ & $(0.006)$ & $(0.006)$ \\
& & 0.004 & 0.005 & 0.009 & 0.011 \\
Year Fixed Effects & & $(0.007)$ & $(0.007)$ & $(0.007)$ & $(0.007)$ \\
Age and Gender Controls & Yes & Yes & Yes & Yes & Yes \\
Parental Education Controls & No & No & Yes & Yes & Yes \\
University Experience Controls & No & No & No & Yes & Yes \\
Program Fixed Effects & No & No & Yes & Yes & Yes \\
Observations & No & No & No & No & Yes \\
R-squared & 216,747 & 216,747 & 216,747 & 213,401 & 213,401 \\
\end{tabular}

Table 21 - Admission Probability without INCLUSP (2001 - 2002)

\begin{tabular}{lccccc}
\hline \hline & $(1)$ & $(2)$ & $(3)$ & $(4)$ & $(5)$ \\
Public High School & & & & & \\
& $-0.041^{* * *}$ & $-0.042^{* * *}$ & $-0.042^{* * *}$ & $-0.019^{* * *}$ & $-0.031^{* * *}$ \\
Visible Minority & $(0.002)$ & $(0.002)$ & $(0.002)$ & $(0.002)$ & $(0.002)$ \\
& $-0.021^{* * *}$ & $-0.023^{* * *}$ & $-0.028^{* * *}$ & $-0.015^{* * *}$ & $-0.019^{* * *}$ \\
Public HS x AA Years & $(0.003)$ & $(0.004)$ & $(0.004)$ & $(0.004)$ & $(0.004)$ \\
& -0.002 & -0.001 & -0.001 & 0.000 & -0.001 \\
Visible Minority x Public HS & $(0.002)$ & $(0.003)$ & $(0.003)$ & $(0.003)$ & $(0.003)$ \\
& 0.001 & 0.004 & $0.010^{*}$ & 0.006 & $0.009^{*}$ \\
Visible Minority x AA Years & $(0.004)$ & $(0.005)$ & $(0.005)$ & $(0.005)$ & $(0.005)$ \\
& 0.000 & 0.003 & 0.004 & 0.002 & 0.003 \\
Visible Minority x Public HS x AA Years & $(0.003)$ & $(0.006)$ & $(0.006)$ & $(0.006)$ & $(0.006)$ \\
& & -0.005 & -0.005 & -0.004 & -0.006 \\
Year Fixed Effects & Yes & $(0.007)$ & $(0.007)$ & $(0.007)$ & $(0.007)$ \\
Age and Gender Controls & Yes & Yes & Yes & Yes \\
Parental Education Controls & No & No & Yes & Yes & Yes \\
University Experience Controls & No & No & Yes & Yes & Yes \\
Program Fixed Effects & No & No & No & No & Yes \\
\hline Observations & 219,334 & 219,334 & 219,334 & 216,517 & 216,517 \\
R-squared & 0.007 & 0.007 & 0.019 & 0.025 & 0.070 \\
\hline \hline
\end{tabular}


Table 22 - Admission Probability without INCLUSP (2002 - 2003)

\begin{tabular}{lccccc}
\hline \hline & $(1)$ & $(2)$ & $(3)$ & $(4)$ & $(5)$ \\
& & & & & \\
Public High School & $-0.043^{* * *}$ & $-0.043^{* * *}$ & $-0.042^{* * *}$ & $-0.019^{* * *}$ & $-0.029^{* * *}$ \\
& $(0.002)$ & $(0.002)$ & $(0.002)$ & $(0.002)$ & $(0.002)$ \\
Visible Minority & $-0.019^{* * *}$ & $-0.020^{* * *}$ & $-0.023^{* * *}$ & $-0.012^{* * *}$ & $-0.015^{* * *}$ \\
& $(0.003)$ & $(0.004)$ & $(0.004)$ & $(0.004)$ & $(0.004)$ \\
Public HS x AA Years & 0.003 & 0.003 & 0.003 & 0.003 & 0.002 \\
& $(0.002)$ & $(0.003)$ & $(0.003)$ & $(0.003)$ & $(0.003)$ \\
Visible Minority x Public HS & -0.002 & -0.001 & 0.004 & 0.001 & 0.005 \\
& $(0.003)$ & $(0.005)$ & $(0.005)$ & $(0.005)$ & $(0.005)$ \\
Visible Minority x AA Years & -0.003 & -0.002 & -0.002 & -0.002 & -0.001 \\
& $(0.003)$ & $(0.005)$ & $(0.005)$ & $(0.005)$ & $(0.005)$ \\
Visible Minority x Public HS x AA Years & & -0.002 & -0.001 & -0.002 & -0.001 \\
& & $(0.007)$ & $(0.007)$ & $(0.007)$ & $(0.007)$ \\
Year Fixed Effects & Yes & Yes & Yes & Yes & Yes \\
Age and Gender Controls & No & No & Yes & Yes & Yes \\
Parental Education Controls & No & No & No & Yes & Yes \\
University Experience Controls & No & No & Yes & Yes & Yes \\
Program Fixed Effects & No & No & No & No & Yes \\
\hline Observations & 237,082 & 237,082 & 237,082 & 235,067 & 235,067 \\
R-squared & 0.007 & 0.007 & 0.017 & 0.023 & 0.060 \\
\hline \hline
\end{tabular}

Table 23 - Admission Probability without INCLUSP (2003 - 2004)

\begin{tabular}{lccccc}
\hline \hline & $(1)$ & $(2)$ & $(3)$ & $(4)$ & $(5)$ \\
Public High School & & & & & \\
& $-0.039^{* * *}$ & $-0.040^{* * *}$ & $-0.038^{* * *}$ & $-0.016^{* * *}$ & $-0.028^{* * *}$ \\
Visible Minority & $(0.002)$ & $(0.002)$ & $(0.002)$ & $(0.002)$ & $(0.002)$ \\
& $-0.021^{* * *}$ & $-0.022^{* * *}$ & $-0.024^{* * *}$ & $-0.014^{* * *}$ & $-0.016^{* * *}$ \\
Public HS x AA Years & $(0.003)$ & $(0.004)$ & $(0.004)$ & $(0.004)$ & $(0.004)$ \\
& 0.002 & 0.002 & 0.001 & 0.002 & -0.000 \\
Visible Minority x Public HS & $(0.002)$ & $(0.003)$ & $(0.003)$ & $(0.003)$ & $(0.003)$ \\
& -0.004 & -0.003 & 0.002 & -0.000 & 0.002 \\
Visible Minority x AA Years & $(0.003)$ & $(0.005)$ & $(0.005)$ & $(0.005)$ & $(0.004)$ \\
& -0.004 & -0.003 & -0.002 & -0.003 & -0.003 \\
Visible Minority x Public HS x AA Years & $(0.003)$ & $(0.005)$ & $(0.005)$ & $(0.005)$ & $(0.005)$ \\
& & -0.002 & -0.003 & -0.001 & -0.001 \\
Year Fixed Effects & & $(0.006)$ & $(0.006)$ & $(0.006)$ & $(0.006)$ \\
Age and Gender Controls & Yes & Yes & Yes & Yes & Yes \\
Parental Education Controls & No & No & Yes & Yes & Yes \\
University Experience Controls & No & No & No & Yes & Yes \\
Program Fixed Effects & No & No & Yes & Yes & Yes \\
\hline Observations & No & No & No & No & Yes \\
R-squared & 249,965 & 249,965 & 249,965 & 247,782 & 247,782 \\
\hline \hline & 0.007 & 0.007 & 0.016 & 0.021 & 0.066 \\
\hline
\end{tabular}


Table 24 - Admission and Affirmative Action (2006 - 2009)

\begin{tabular}{lccccc}
\hline \hline & $(1)$ & $(2)$ & $(3)$ & $(4)$ & $(5)$ \\
Public High School & $-0.055^{* * *}$ & $-0.058^{* * *}$ & $-0.058^{* * *}$ & $-0.031^{* * *}$ & $-0.041^{* * *}$ \\
& $(0.002)$ & $(0.002)$ & $(0.002)$ & $(0.002)$ & $(0.002)$ \\
Visible Minority & $-0.016^{* * *}$ & $-0.026^{* * *}$ & $-0.028^{* * *}$ & $-0.017^{* * *}$ & $-0.021^{* * *}$ \\
& $(0.003)$ & $(0.003)$ & $(0.003)$ & $(0.003)$ & $(0.003)$ \\
Public HS x AA Years & $0.054^{* * *}$ & $0.059^{* * *}$ & $0.052^{* * *}$ & $0.048^{* * *}$ & $0.039^{* * *}$ \\
& $(0.002)$ & $(0.003)$ & $(0.003)$ & $(0.003)$ & $(0.003)$ \\
Visible Minority x Public HS & $-0.019^{* * *}$ & -0.005 & -0.000 & -0.001 & 0.003 \\
& $(0.003)$ & $(0.004)$ & $(0.004)$ & $(0.004)$ & $(0.004)$ \\
Visible Minority x AA Years & -0.001 & $0.013^{* * *}$ & $0.012^{* * *}$ & $0.011^{* *}$ & $0.010^{* *}$ \\
& $(0.003)$ & $(0.004)$ & $(0.004)$ & $(0.004)$ & $(0.004)$ \\
Visible Minority x Public HS x AA Years & & $-0.024^{* * *}$ & $-0.024^{* * *}$ & $-0.022^{* * *}$ & $-0.025^{* * *}$ \\
& & $(0.005)$ & $(0.005)$ & $(0.005)$ & $(0.005)$ \\
Year Fixed Effects & Yes & Yes & Yes & Yes & Yes \\
Age and Gender Controls & No & No & Yes & Yes & Yes \\
Parental Education Controls & No & No & No & Yes & Yes \\
University Experience Control & No & No & Yes & Yes & Yes \\
Program Fixed Effects & No & No & No & No & Yes \\
& & & & & \\
\hline Observations & 379,120 & 379,120 & 379,120 & 371,990 & 371,990 \\
R-squared & 0.007 & 0.007 & 0.020 & 0.024 & 0.070 \\
\hline \hline
\end{tabular}

Table 25 - Admission and Affirmative Action (2006 - 2012)

\begin{tabular}{lccccc}
\hline \hline & $(1)$ & $(2)$ & $(3)$ & $(4)$ & $(5)$ \\
Public High School & $-0.055^{* * *}$ & $-0.058^{* * *}$ & $-0.060^{* * *}$ & $-0.033^{* * *}$ & $-0.038^{* * *}$ \\
& $(0.002)$ & $(0.002)$ & $(0.002)$ & $(0.002)$ & $(0.002)$ \\
Visible Minority & $-0.018^{* * *}$ & $-0.026^{* * *}$ & $-0.029^{* * *}$ & $-0.018^{* * *}$ & $-0.020^{* * *}$ \\
& $(0.003)$ & $(0.004)$ & $(0.004)$ & $(0.004)$ & $(0.003)$ \\
Public HS x AA Years & $0.057^{* * *}$ & $0.060^{* * *}$ & $0.051^{* * *}$ & $0.045^{* * *}$ & $0.033^{* * *}$ \\
& $(0.002)$ & $(0.002)$ & $(0.002)$ & $(0.002)$ & $(0.002)$ \\
Visible Minority x Public HS & $-0.017^{* * *}$ & -0.005 & -0.000 & -0.001 & 0.002 \\
& $(0.002)$ & $(0.004)$ & $(0.004)$ & $(0.004)$ & $(0.004)$ \\
Visible Minority x AA Years & -0.001 & $0.009^{* *}$ & $0.007^{*}$ & 0.006 & 0.005 \\
& $(0.002)$ & $(0.004)$ & $(0.004)$ & $(0.004)$ & $(0.004)$ \\
Visible Minority x Public HS x AA Years & & $-0.016^{* * *}$ & $-0.018^{* * *}$ & $-0.017^{* * *}$ & $-0.022^{* * *}$ \\
& & $(0.005)$ & $(0.005)$ & $(0.005)$ & $(0.005)$ \\
Year Fixed Effects & Yes & Yes & Yes & Yes & Yes \\
Age and Gender Controls & No & No & Yes & Yes & Yes \\
Parental Education Controls & No & No & No & Yes & Yes \\
University Experience Control & No & No & Yes & Yes & Yes \\
Program Fixed Effects & No & No & No & No & Yes \\
& & & & & \\
\hline Observations & 710,893 & 710,893 & 710,893 & 691,730 & 691,730 \\
R-squared & 0.006 & 0.006 & 0.021 & 0.025 & 0.086 \\
\hline \hline
\end{tabular}


Table 26 - Admission and Affirmative Action (2006 - 2013)

\begin{tabular}{lccccc}
\hline \hline & $(1)$ & $(2)$ & $(3)$ & $(4)$ & $(5)$ \\
Public High School & $-0.055^{* * *}$ & $-0.058^{* * *}$ & $-0.061^{* * *}$ & $-0.034^{* * *}$ & $-0.037^{* * *}$ \\
& $(0.002)$ & $(0.002)$ & $(0.002)$ & $(0.002)$ & $(0.002)$ \\
Visible Minority & $-0.018^{* * *}$ & $-0.026^{* * *}$ & $-0.029^{* * *}$ & $-0.018^{* * *}$ & $-0.020^{* * *}$ \\
& $(0.002)$ & $(0.004)$ & $(0.004)$ & $(0.004)$ & $(0.003)$ \\
Public HS x AA Years & $0.057^{* * *}$ & $0.060^{* * *}$ & $0.050^{* * *}$ & $0.045^{* * *}$ & $0.032^{* * *}$ \\
& $(0.002)$ & $(0.002)$ & $(0.002)$ & $(0.002)$ & $(0.002)$ \\
Visible Minority x Public HS & $-0.017^{* * *}$ & -0.005 & -0.000 & -0.001 & 0.002 \\
& $(0.002)$ & $(0.004)$ & $(0.004)$ & $(0.004)$ & $(0.004)$ \\
Visible Minority x AA Years & -0.002 & $0.007^{*}$ & 0.006 & 0.005 & 0.004 \\
& $(0.002)$ & $(0.004)$ & $(0.004)$ & $(0.004)$ & $(0.004)$ \\
Visible Minority x Public HS x AA Years & & $-0.015^{* * *}$ & $-0.017^{* * *}$ & $-0.017^{* * *}$ & $-0.021^{* * *}$ \\
& & $(0.005)$ & $(0.005)$ & $(0.005)$ & $(0.005)$ \\
Year Fixed Effects & Yes & Yes & Yes & Yes & Yes \\
Age and Gender Controls & No & No & Yes & Yes & Yes \\
Parental Education Controls & No & No & No & Yes & Yes \\
University Experience Control & No & No & Yes & Yes & Yes \\
Program Fixed Effects & No & No & No & No & Yes \\
& & & & & \\
\hline Observations & 833,177 & 833,177 & 833,177 & 814,014 & 814,014 \\
R-squared & 0.005 & 0.005 & 0.021 & 0.025 & 0.095 \\
\hline \hline
\end{tabular}

Table 27 - Competitive Majors and Affirmative Action (2004 - 2014)

\begin{tabular}{lccccc}
\hline & $(1)$ & $(2)$ & $(3)$ & $(4)$ & $(5)$ \\
Public High School & & & & & \\
& $-0.027^{* * *}$ & $-0.028^{* * *}$ & $-0.027^{* * *}$ & $-0.013^{* * *}$ & $-0.010^{* * *}$ \\
Visible Minority & $(0.001)$ & $(0.001)$ & $(0.001)$ & $(0.001)$ & $(0.001)$ \\
& $-0.009^{* * *}$ & $-0.012^{* * *}$ & $-0.013^{* * *}$ & $-0.007^{* * *}$ & $-0.007^{* * *}$ \\
Public HS x AA Years & $(0.001)$ & $(0.001)$ & $(0.001)$ & $(0.001)$ & $(0.001)$ \\
& $0.017^{* * *}$ & $0.019^{* * *}$ & $0.017^{* * *}$ & $0.016^{* * *}$ & $0.013^{* * *}$ \\
Visible Minority x Public HS & $(0.001)$ & $(0.001)$ & $(0.001)$ & $(0.001)$ & $(0.001)$ \\
& -0.000 & $0.005^{* * *}$ & $0.006^{* * *}$ & $0.004^{* * *}$ & $0.005^{* * *}$ \\
Visible Minority x AA Years & $(0.001)$ & $(0.001)$ & $(0.001)$ & $(0.001)$ & $(0.001)$ \\
& 0.000 & $0.004^{* * *}$ & $0.004^{* * *}$ & $0.004^{* * *}$ & 0.002 \\
Visible Minority x Public HS x AA Years & $(0.001)$ & $(0.001)$ & $(0.001)$ & $(0.001)$ & $(0.001)$ \\
& & $-0.008^{* * *}$ & $-0.008^{* * *}$ & $-0.008^{* * *}$ & $-0.006^{* * *}$ \\
Year Fixed Effects & & $(0.041)$ & $(0.041)$ & $(0.042)$ & $(0.040)$ \\
Age and Gender Controls & Yes & Yes & Yes & Yes & Yes \\
Parental Education Controls & No & No & Yes & Yes & Yes \\
University Experience Controls & No & No & No & Yes & Yes \\
Program Fixed Effects & No & No & Yes & Yes & Yes \\
\hline Observations & No & No & No & No & Yes \\
R-squared & $1,200,105$ & $1,200,105$ & $1,200,105$ & $1,178,666$ & $1,178,666$ \\
& 0.004 & 0.004 & 0.009 & 0.015 & 0.041
\end{tabular}

